\title{
Integrated systems for biopolymers and bioenergy production from organic waste and by-products: a review of microbial processes
}

\author{
Giorgia Pagliano ${ }^{1}$, Valeria Ventorino ${ }^{1}$, Antonio Panico ${ }^{2}$ and Olimpia Pepe ${ }^{1 *}$
}

\begin{abstract}
Recently, issues concerning the sustainable and harmless disposal of organic solid waste have generated interest in microbial biotechnologies aimed at converting waste materials into bioenergy and biomaterials, thus contributing to a reduction in economic dependence on fossil fuels. To valorize biomass, waste materials derived from agriculture, food processing factories, and municipal organic waste can be used to produce biopolymers, such as biohydrogen and biogas, through different microbial processes. In fact, different bacterial strains can synthesize biopolymers to convert waste materials into valuable intracellular (e.g., polyhydroxyalkanoates) and extracellular (e.g., exopolysaccharides) bioproducts, which are useful for biochemical production. In particular, large numbers of bacteria, including Alcaligenes eutrophus, Alcaligenes latus, Azotobacter vinelandii, Azotobacter chroococcum, Azotobacter beijerincki, methylotrophs, Pseudomonas spp., Bacillus spp., Rhizobium spp., Nocardia spp., and recombinant Escherichia coli, have been successfully used to produce polyhydroxyalkanoates on an industrial scale from different types of organic byproducts. Therefore, the development of high-performance microbial strains and the use of by-products and waste as substrates could reasonably make the production costs of biodegradable polymers comparable to those required by petrochemical-derived plastics and promote their use. Many studies have reported use of the same organic substrates as alternative energy sources to produce biogas and biohydrogen through anaerobic digestion as well as dark and photofermentation processes under anaerobic conditions. Therefore, concurrently obtaining bioenergy and biopolymers at a reasonable cost through an integrated system is becoming feasible using by-products and waste as organic carbon sources. An overview of the suitable substrates and microbial strains used in low-cost polyhydroxyalkanoates for biohydrogen and biogas production is given. The possibility of creating a unique integrated system is discussed because it represents a new approach for simultaneously producing energy and biopolymers for the plastic industry using by-products and waste as organic carbon sources.
\end{abstract}

Keywords: Biochemicals and bioenergy, Biopolymers, PHAs, Biogas, Biohydrogen

\section{Background}

Over the past few decades, the need to reduce pollutant emissions produced by conventional systems of organic waste disposal has promoted the development of

\footnotetext{
*Correspondence: olipepe@unina.it

${ }^{1}$ Division of Microbiology, Department of Agricultural Sciences, University of Naples Federico II, Via Università 100, Portici, 80055 Naples, Italy

Full list of author information is available at the end of the article
}

technologies that convert organic waste into bioenergy and biomaterials. In the near future, this new approach in waste management, in addition to being eco-friendly, can reasonably replace fossil fuels with biomass (organic waste or energy crops) as a source of both energy and materials (e.g., plastics) and therefore make two contributions toward reducing greenhouse gas (GHG) emissions into the atmosphere [1].

Petrochemical-derived materials can be replaced with biodegradable materials and biochemicals derived from 
renewable sources. In fact, organic waste materials are interesting renewable resources that can be converted into different value-added products, such as bioethanol or biochemicals obtained by sugar fermentation [2, 3]. Recent technological developments have explored the value of biochemical products as precursors to biopolymers, e.g., succinic acid [4, 5] and 2,3-butanediol [6] derived from lignocellulosic biomass. Some biopolymers can be produced by microorganisms from the accumulation of extracellular materials, such as exopolysaccharides (EPS) [7], and used in the food, chemical, cosmetic, and packaging industries as adhesives, absorbents, lubricants, and cosmetics. Furthermore, several biopolymers, such as polyhydroxyalkanoates (PHAs), polylactides, aliphatic polyesters, and polysaccharides [8], have already been successfully tested as bioplastics [9] because their physical and chemical properties perform just as well as conventional synthetic plastics. Among them, PHAs have gained much attention thanks to their complete biodegradability under various conditions within a period of 1 year [10]. Different bacteria (e.g., Alcaligenes spp., Azotobacter spp., methylotrophs, Pseudomonas spp., Bacillus spp., and recombinant Escherichia coli) have been used in PHA production from different low-cost substrates. In fact, to replace conventional petrochemical-derived plastics, useful substrates for PHA production include organic waste and by-products. In fact, to commercialize PHAs, substantial effort has been devoted to reducing the production cost through the development of bacterial strains and more efficient fermentation/recovery processes because the price of the substrate has the largest influence on the production cost of PHA [11].

To make PHA production more feasible for industrial application, future prospects are mainly focused on promoting less expensive substrates, improved microorganism cultivation strategies, and easier downstream processing methods, which are required for reducing production costs [12]. For this reason, different inexpensive substrates, such as molasses and sucrose, starchbased materials, cellulosic and hemicellulosic materials, sugars, whey, oils, fatty acids and glycerol, and organic matter from waste and wastewater [13], have been tested to produce biopolymers, and the results are promising.

Furthermore, it is important to highlight that the same substrates used to produce biopolymers represent a source of renewable energy (biomethane and biohydrogen) obtainable through an anaerobic digestion process. Therefore, such substrates can be simultaneously used to produce bioenergy and biopolymers, thus achieving a maximum valorization when they are used as organic waste.

The anaerobic digestion process is characterized by biochemical reactions in series carried out by different consortia of bacteria that convert organic compounds into methane, carbon dioxide, water, and ammonia. In the first step, complex and not negligibly sized biomolecules of organic materials are disintegrated and subsequently hydrolyzed into soluble, biodegradable organics by extracellular enzymes [14]. Then, acidogenic microorganisms metabolize products by hydrolysis into volatile fatty acids (VFAs) (acidogenic phase) [15]. Acidogenic products are first converted into acetic acid, hydrogen, and carbon dioxide (acetogenic phase) and, finally, into methane by methane-producing Archaea (methanogenic phase) [16]. The same substrates of methanogenic metabolism are the precursors that form PHAs [17]. Thus, this review gives insights into the current methodology for producing PHAs and biogas, with a focus on the use of organic waste and by-products as raw materials to keep production costs low. Moreover, this review examines the potential of several biological processes that can occur in the development of an innovative unique integrated system able to simultaneously produce bioenergy and biopolymers.

\section{Bio-based and biodegradable polymers: PHAs production and classification}

Polyhydroxyalkanoates (PHAs) represent a group of biobased and biodegradable polymers, considered similar to petroleum-based polymers [18].

Many bacteria, such as Cupriavidus (C.) necator [10, 19-27], different Pseudomonas (P.) species (P. fluorescens, $P$. hydrogenovora, $P$. oleovorans, $P$. resinovorans, $P$. aeruginosa, $P$. mendocina) [25, 28-32], strains belonging to Azotobacter (A.) species (A. vinelandii, A. chroococcum, A. beijerinckii) [33-37], Bacillus (B.) spp. [38-40], recombinant Escherichia (E.) coli [8, 12, 35, 41-44], and Burkholderia (Bk.) spp. [45, 46], synthesize PHAs as intracellular carbon and energy storage, accumulating these polyesters of hydroxyalkanoates as granules in the cytoplasm of cells [47]. Polyhydroxyalkanoic acids produced by bacteria are the building blocks of biodegradable thermoplastics and elastomers currently in use, or candidates to be used, in the medical and pharmaceutical industries as well as in agriculture [48]. The production of PHAs occurs mainly when cells are cultivated in the presence of a carbon source in excess, and their growth is limited by the lack of another nutrient, such as nitrogen, phosphorus, sulfur, or oxygen [49]. When the supply of the limiting nutrient is restored, PHAs are degraded by an intracellular depolymerase and subsequently metabolized as a carbon and energy source [50], and the number of bacteria rapidly increases.

Polyhydroxyalkanoates can be divided into two groups depending on the number of carbon atoms in the monomer units: short-chain-length (SCL) PHAs, which consist 
of 3-5 carbon atoms, and medium-chain-length MCLPHAs, which consist of 6-14 carbon atoms [49]. The length of the side chain and functional group has great importance for the physical properties. The SCL-PHAs are crystalline, brittle, and stiff polymers, with a high melting point and a low glass transition temperature. In contrast, MCL-PHAs show low crystallinity and tensile strength and lower melting points.

Polyhydroxyalkanoates have the general formula shown in Fig. 1 [13], where " $n$ " is equal to 1 , and " $R$ " is a methyl group. The most abundant PHA family member is poly(3-hydroxybutyrate) $(\mathrm{P}(3 \mathrm{HB}))$. Using different substrates in a co-feeding system, copolymers of PHB (polyhydroxybutyrate) can be formed, such as polymers containing 3-hydroxyvalerate (3HV) or 4-hydroxybutyrate $(4 \mathrm{HB})$ monomers. $3 \mathrm{HV}$ can be incorporated into the PHB molecule, forming poly(3-hydroxybutyrate-co3-hydroxyvalerate) $[\mathrm{P}(3 \mathrm{HB}-3 \mathrm{HV})]$, resulting in a more brittle compound than $\mathrm{P}(3 \mathrm{HB})$ [47].

Thus, to reduce the environmental footprint by producing and using petrochemical-derived products, they can be replaced partially and even completely by polyesters derived from biological processes (i.e., PHAs) that have the significant advantage of being completely biocompatible [47]. Biocompatibility is the property shown by certain materials that generates non-toxic compounds when they are disposed of after use as well having the same physical property of the artificial material derived from petrol that they would replace [13]. Unlike petroleumderived plastics that take several decades to degrade, PHAs can be completely bio-degraded within a year by a variety of microorganisms, mainly bacteria and fungi [48]. In particular, several aerobic and anaerobic PHAdegrading bacteria, such as Comamonas sp. [51], Pseudomonas lemoignei [52] from soil, Alcaligenes faecalis [53] and Pseudomonas fluorescens from activated sludge

\begin{tabular}{|c|c|c|}
\hline & $\left(\mathrm{O}-\stackrel{\mathrm{C}}{\mathrm{CH}}^{\mathrm{R}}\right.$ & $I_{n}-\left.\stackrel{O}{C}\right|_{100-3000}$ \\
\hline \multirow[t]{6}{*}{$n=1$} & $R=$ hydrogen & poly(3-hydroxypropionate) \\
\hline & $R=$ methyl & poly(3-hydroxybutyrate) \\
\hline & $\mathrm{R}=$ ethyl & poly(3-hydroxyvalerate) \\
\hline & $\mathrm{R}=$ propyl & poly(3-hydroxyhexanoate) \\
\hline & $\mathrm{R}=$ pentyl & poly(3-hydroxyoctanoate) \\
\hline & $\mathrm{R}=$ nonyl & poly(3-hydroxydodecanoate) \\
\hline \multirow[t]{2}{*}{$n=2$} & $R=$ hydrogen & poly(4-hydroxybutyrate) \\
\hline & $R=$ methyl & poly(4-hydroxyvalerate) \\
\hline \multirow[t]{2}{*}{$n=3$} & $R=$ hydrogen & poly(5-hydroxyvalerate) \\
\hline & $\mathrm{R}=$ methyl & poly(5-hydroxyhexanate) \\
\hline$n=4$ & $R=$ hexyl & poly(6-hydroxydodecanoate) \\
\hline
\end{tabular}

Fig. 1 General structure of polyhydroxyalkanoates (PHAs). The most studied PHA type is the homopolymer P(3HB), for which $n$ is equal to 1 and $R$ is a methyl group [13]
[54] and Pseudomonus stutzeri from lake water [55], and fungi, such as Aspergillus fumigatus [54], have been isolated from various environments. These microorganisms excrete extracellular PHA depolymerases to degrade PHAs into water-soluble monomers and oligomers, using them as a carbon source (or methane under anaerobic conditions) [8].

Thus, life cycle assessment (LCA) conducted on the use of PHAs has been proven as the main advantage to avoid the accumulation of plastics in the environment [56]. Therefore, PHAs are better than petrochemical analogues, such as polyethylene and polypropylene [57-59], in terms of sustainability and environmental protection [60], but the realization and more widespread use of these environmentally friendly processes are related to the cost of the final product. The current PHA price also depends on monomer composition, and it is usually higher for copolymers; overall, it ranges from 2.2 to $5.0 € \mathrm{~kg}^{-1}[13,61,62]$, which is less than the typical range of $10-12 € \mathrm{~kg}^{-1}$ reported at the beginning of the past decade [61]. Notwithstanding the burden of costs and the environmental impacts of plastic trash, the current PHA prices are not deemed to be commercially competitive with respect to conventional petroleum-based polymers, which typically cost less than $1.0 € \mathrm{~kg}^{-1}[61$, 63]. Although the price of PHAs is high, several companies are producing PHA products worldwide to meet the demand of the market, including in the UK, Japan, US, Germany, Brazil, Italy, and China $[64,65]$.

\section{Suitable substrates and bacterial strains for PHA production}

The synthesis of PHAs occurs in many microorganisms under well-defined operating conditions and when they are supplemented with specific substrates, better known as PHA precursors. These compounds are incorporated into PHAs and used as the sole carbon source by microorganisms (or coupled with others as cosubstrates) if the cells are cultivated in the presence of an excess carbon source. Moreover, PHAs are also formed when growth is impaired or restricted by the lack of another nutrient, such as nitrogen, phosphorus, or oxygen [8]. Thus, different PHAs could be synthesized from the combination of different substrates and microorganisms under different growth conditions (aerobic or anaerobic, temperature, and $\mathrm{pH}$ ).

Relevant substrates for the production of PHAs are as follows: carbon dioxide [66] or fossil resources, such as low-rank coal [67] renewable resources (e.g., starch $[19,20,26,38,68]$, cellulose [69], sucrose [28, 33, 45]), waste materials (e.g., molasses [33, 39, 41], whey [12, 29, 42-44], glycerol [10]), and chemicals (e.g., propionic acid [70]). To avoid the use of fossil resources due to 
environmental issues and to limit PHA production costs, renewable resource and waste materials are reasonably considered suitable and promising substrates.

In the following paragraphs, an overview of different works categorized on the basis of the different substrates used is given. The results are presented in terms of the PHA content (\%PHAs, \%) and concentration ([PHAs], $\mathrm{g}^{-1}$ ) calculated by the following Eqs. 1 and 2, respectively, where mPHA is the amount of PHAs (mg), mcells (mg) is the amount of freeze-dried biomass in samples, and CDW is the cell dry weight $\left(\mathrm{g} \mathrm{l}^{-1}\right)$ :

$$
\begin{aligned}
& \% \text { PHAs }=\frac{\text { mPHAs }}{\text { mcells }} \times 100 \\
& {[\text { PHAs }]=\frac{\% \text { PHAs }}{100} \times \mathrm{CDW} .}
\end{aligned}
$$

\section{Starch-based material as a source of PHAs}

Starch is a renewable carbon source available in large amounts. Prior to fermentation, starch is hydrolyzed to glucose by a two-step process, liquefaction and saccharification, because PHA-producing bacteria cannot synthesize amylase enzymes for starch degradation. Commercial hydrolyzing enzymes are often used, but they contribute to an increase in the cost of the glucose production process [35]. Kim [35] used soluble starch to produce $\mathrm{P}(3 \mathrm{HB})$, obtained after $70 \mathrm{~h}$ of incubation with $25 \mathrm{~g} \mathrm{l}^{-1}$ of PHB (content of $46 \%$ in cell dry weight), in fedbatch cultures of $A$. chroococcum strain 23 under oxygenlimiting conditions. Halami [38] reported the ability of the isolated strain Bacillus cereus CFR06 to accumulate PHAs in a starch medium composed of soluble starch, yeast extract, and salts. The genus Bacillus was identified as one of the first gram-positive bacteria suitable to produce PHAs and was cultivated under nitrogen limitation in Luria-Bertani (LB) broth for $24 \mathrm{~h}$ at $37^{\circ} \mathrm{C}$ on a rotary shaker at $100-150 \mathrm{rpm} \mathrm{min}^{-1}$. The results obtained were less promising than those found by Kim [35] because, after $72 \mathrm{~h}$ of incubation, a $\mathrm{P}(3 \mathrm{HB})$ concentration of $0.48 \mathrm{~g} \mathrm{l}^{-1}$ with a content of $48 \%$ was achieved. Koutinas et al. [19] proved the potential of $C$. necator (synonym Wautersia eutropha and formerly classified as Alcaligenes eutrophus, formerly classified as Ralstonia (R.) eutropha [68]) in PHB production from a specific substrate derived from wheat. The authors conducted fed-batch tests using a $500-\mathrm{ml}$ shake flask on a $250 \mathrm{rpm}$ rotary shaker at $30^{\circ} \mathrm{C}$ and a $\mathrm{pH}$ range of 6.5-6.8. The results showed a PHB concentration of $51.1 \mathrm{~g} \mathrm{l}^{-1}$ using a culture medium with free amino nitrogen as substrate at a concentration of $1.2 \mathrm{~g} \mathrm{l}^{-1}$. Under the same operating conditions (working volume, $\mathrm{rpm}$, temperature, and $\mathrm{pH}$ range), $\mathrm{Xu}$ et al. [20] compared the batch and fed-batch modes using $C$. necator NCIMB 11599 grown on wheat-derived media. They demonstrated that more PHB was accumulated in cells operating in fed-batch mode. In fact, the use of fedbatch mode allowed for an increase in PHB concentration to $130.2 \mathrm{~g} \mathrm{l}^{-1}$ (PHB cells content $~ 80 \%$ ) compared with batch fermentation that showed a production of $41.5 \mathrm{~g} \mathrm{PHB} \mathrm{l}^{-1}$ (PHB cells content $\sim 66 \%$ ). Haas et al. [21] used saccharified waste potato starch as a carbon source for PHB production by C. necator NCIMB 11599, obtaining a PHB concentration of $94 \mathrm{~g} \mathrm{l}^{-1}$, with a specific yield from starch of 0.22 PHB g starch $g^{-1}$ under phosphatelimiting conditions. Poomipuk et al. [71] isolated and selected the strain Cupriavidus sp. KKU38, which was able to accumulate PHAs up to $65.27 \%$ (PHA concentration of $2.8 \mathrm{~g} \mathrm{l}^{-1}$ ) from cassava starch hydrolysate as a sole carbon source in a $250-\mathrm{ml}$ flask (Table 1 ).

However, to overcome the high costs of the hydrolysis of starch into glucose by a two-step process (liquefaction and saccharification), making this feedstock less economically viable, Bhatia et al. [72] constructed the recombinant E. coli strain SKB99 harboring plasmids containing genes for starch hydrolysis (from Paenibacillus sp.) and PHB synthesis (from R. eutropha). This engineered strain utilized starch as the sole carbon source, with a maximum

\begin{tabular}{|c|c|c|c|c|c|c|}
\hline Strain & Type of PHA & Operation mode & Time to $\mathrm{PHA}_{\max }[\mathrm{h}]$ & PHA concentration $\left[\mathrm{g} \mathrm{I}^{-1}\right]$ & PHA content [\%] & References \\
\hline Azotobacter chroococcum 23 & $\mathrm{P}(3 \mathrm{HB})$ & Fed-batch & 70 & 25 & 46 & [35] \\
\hline Bacillus cereus CFR06 & $\mathrm{P}(3 \mathrm{HB})$ & Batch & 72 & 0.48 & 48 & [38] \\
\hline $\begin{array}{l}\text { Cupriavidus necator NCIMB } \\
11599\end{array}$ & $\mathrm{P}(3 \mathrm{HB})$ & Fed-batch & 168 & 51.1 & 70 & [19] \\
\hline \multirow{2}{*}{$\begin{array}{l}\text { Cupriavidus necator NCIMB } \\
11599\end{array}$} & \multirow[t]{2}{*}{$P(3 \mathrm{HB})$} & Batch & 69 & 41.5 & 66 & \multirow[t]{2}{*}{ [20] } \\
\hline & & Fed-batch & 171 & 130.2 & 80 & \\
\hline $\begin{array}{l}\text { Cupriavidus necator NCIMB } \\
11599\end{array}$ & $\mathrm{P}(3 \mathrm{HB})$ & Batch & 72 & 94 & 22 & [21] \\
\hline Cupriavidus sp. KKU38 & PHA & Batch & 96 & 2.8 & 65.3 & [71] \\
\hline Recombinant E. coli SKB99 & $\mathrm{P}(3 \mathrm{HB})$ & Batch & 72 & 1.2 & 40 & [72] \\
\hline
\end{tabular}

Table 1 Overview of studies reporting PHA production from starch-based materials 
PHB production of $1.24 \mathrm{gl}^{-1}$ (PHB content $40 \%$ ) for $72 \mathrm{~h}$ with $2 \%(\mathrm{w} / \mathrm{v})$ starch (Table 1$)$. In addition, the accumulation of PHB started with the growth of the strain E. coli SKB99 and remained consistent until it attained the stationary phase, highlighting that PHB production in this engineered strain is not regulated by the stress response, unlike in $R$. eutropha and other microorganisms.

Therefore, starch-based materials are suitable substrates for PHA accumulation and, in particular, for $\mathrm{P}(3 \mathrm{HB})$ accumulation. However, PHA accumulation strictly depends on the bacterial species and strains that exhibit different biotechnological performances depending on the carbon source and the culture conditions. The best results were obtained using C. necator NCIMB 11599 cultured on wheat and hydrolyzed waste potatoes under nutrient (nitrogen or phosphorus)-limiting conditions, operating in batch and fed-batch mode, respectively.

\section{Molasses and sucrose as sources for PHAs}

Molasses is a common industrial by-product of sugar production, is much cheaper than glucose, and is extensively used as a carbon source for PHA production from biological processes. Liu et al. [41] demonstrated that recombinant $E$. coli (HMS174/pTZ18u-PHB) can efficiently utilize molasses as the sole carbon source to produce PHB. A fed-batch feeding strategy was developed to improve cell growth and PHB production. The final PHA concentration was $31.6 \mathrm{~g} \mathrm{l}^{-1}$, and $80 \%$ of PHAs was accumulated (Table 2). Jiang et al. [28] isolated a strain of (PHB)-accumulating bacteria from the soil in Alaska (USA), identified as $P$. fluorescens A2a5. This microorganism is capable of accumulating a large amount of granules in its cells when grown in sugarcane liquor medium. Batch cultivation was carried out at $25{ }^{\circ} \mathrm{C}$ in a 5-l bioreactor inoculated with $1 \%$ inoculum $(\mathrm{v} / \mathrm{v})$ at $\mathrm{pH}$ 7.0. In this way, a maximum cell dry weight $(\mathrm{CDW})$ of $32 \mathrm{~g} \mathrm{l}^{-1}$ with a PHB concentration of $22.4 \mathrm{~g} \mathrm{l}^{-1}$ was obtained, and the PHB content was approximately $70 \%$. C. necator was aerobically grown in a well-balanced medium consisting of sugarcane and inorganic nutrients to reach a high cell density [45]. Then, cell growth was shifted to PHB synthesis by limiting nutrients other than the carbon source. The fed-batch fermentation process was carried out by continually feeding $(45-50 \mathrm{~h})$ a high concentration of sugar syrup to achieve a biomass of nearly $65-70 \%$ PHB, with a concentration ranging from 80 to $100 \mathrm{~g} \mathrm{l}^{-1}$ (Table 2).

The effect of different molasses concentrations (1-5 g molasses/100 ml water) on PHB production by $B$. cereus M5 was investigated by Yilmaz and Beyatli [39]. They observed that PHB productivity by this strain decreased with increasing molasses concentration. In fact, the highest $\mathrm{P}(3 \mathrm{HB})$ concentration produced by this strain was $0.1 \mathrm{~g} \mathrm{l}^{-1}$ (polymer content of $73.8 \%$ ) with $1 \%$ molasses concentration.

Azotobacter vinelandii UWD was investigated by Page et al. [33] using molasses as the sole carbon source. Fedbatch bioreactors were operated with $5 \%(\mathrm{w} / \mathrm{v})$ molasses at $\mathrm{pH} 7.2$ and inoculated with $4 \%(\mathrm{v} / \mathrm{v})$ of the pre-grown strain. In the beet molasses medium, $\mathrm{NH}_{4}$ was depleted by $10-12 \mathrm{~h}$ to establish $\mathrm{NH}_{4}$-limiting conditions and fix nitrogen during the PHA production phase of growth. After $35 \mathrm{~h}$, a $\mathrm{P}(3 \mathrm{HB})$ concentration of $23 \mathrm{~g} \mathrm{l}^{-1}$ and a polymer content of $66 \%$ were achieved.

Kulpreecha et al. [73] tested B. megaterium BA-019 on sugarcane molasses $\left(20 \mathrm{~g} \mathrm{l}^{-1}\right)$ as a carbon source and urea or ammonium sulfate at $0.8 \mathrm{~g} \mathrm{l}^{-1}$ as the investigated nitrogen sources. In the experiments, a cell dry mass concentration of $72.7 \mathrm{~g} \mathrm{l}^{-1}$ in $24 \mathrm{~h}$, with a PHB content of $42 \%(\mathrm{w} / \mathrm{w})$, was achieved under nitrogen-limiting conditions operating in fed-batch mode (Table 2).

In addition, with sugarcane, $C$. necator showed the best PHA concentration among the bacterial strains (recombinant E. coli, A. vinelandii UWD, and B. megaterium) operating in fed-batch mode with molasses as a carbon source. In fact, $C$. necator is able to accumulate approximately $100 \mathrm{~g} \mathrm{l}^{-1}$ synthesizing glucose (from starch) and sucrose (from sugarcane).

\section{Lignocellulosic material as a source for PHAs}

To produce fuels and other valuable bioproducts, lignocellulosic biomass from dedicated crops and agricultural

Table 2 Overview of studies reporting PHA production from molasses and sucrose

\begin{tabular}{|c|c|c|c|c|c|c|}
\hline Strain & Type of PHA & Operation mode & Time to $\mathrm{PHA}_{\max }[\mathrm{h}]$ & PHA concentration $\left[\mathrm{g} \mathrm{I}^{-1}\right]$ & PHA content [\%] & References \\
\hline $\begin{array}{l}\text { Recombinant E. coli (HMS174/ } \\
\text { pTZ18u-PHB) (C. necator } \\
\text { genes) }\end{array}$ & $\mathrm{P}(3 \mathrm{HB})$ & Fed-batch & 31.5 & 31.6 & 80 & [41] \\
\hline Pseudomonas fluorescens A2a5 & $\mathrm{P}(3 \mathrm{HB})$ & Batch & 96 & 22.4 & 70 & {$[28]$} \\
\hline Cupriavidus necator & $\mathrm{P}(3 \mathrm{HB})$ & Fed-batch & $45-50$ & $80-100$ & $65-70$ & {$[45]$} \\
\hline Bacillus cereus M5 & $\mathrm{P}(3 \mathrm{HB})$ & Batch & 72 & 0.13 & 73.8 & [39] \\
\hline Azotobacter vinelandii UWD & $\mathrm{P}(3 \mathrm{HB})$ & Fed-batch & 35 & 23 & 66 & [33] \\
\hline Bacillus megaterium BA-019 & $\mathrm{P}(3 \mathrm{HB})$ & Fed-batch & 24 & 72.7 & 42 & [73] \\
\hline
\end{tabular}


and forestry waste are promising renewable sources [74-77].

Lignocellulosic materials, consisting of lignin (complex polyphenolic structure), cellulosic (b-D-1,4-glucan), and hemicellulosic (D-arabinose, D-xylose, D-mannose, D-glucose, D-galactose, and sugar alcohols) fibers, constitute the most abundant renewable resources on our planet [13].

The composition of lignocellulosic biomass differs in terms of lignin (10-25\%), cellulose (30-60\%), and hemicellulose (25-35\%) content [78].

Silva et al. [46] studied the potential of two bacterial strains, Bk. cepacia IPT 048 and Bk. sacchari IPT $101 \mathrm{~A}$, in producing $\mathrm{P}(3 \mathrm{HB})$, comparing biosynthesis from xylose and glucose with bagasse hydrolysate. In high-cell-density cultures using a mixture of xylose and glucose under $\mathrm{P}$ limitation, both strains reached a maximum $\mathrm{P}(3 \mathrm{HB})$ concentration of $60 \mathrm{~g} \mathrm{l}^{-1}$ dry biomass, containing $60 \%$ biopolymer. Higher polymer content and yield were observed under $\mathrm{P}$ limitation than under $\mathrm{N}$ limitation for Bk. sacchari IPT 101A, whereas Bk. cepacia IPT 048 showed a similar performance in the presence of both growth-limiting nutrient conditions. Using bagasse hydrolysate as the carbon source, polymer contents reached 62 and $53 \%$ for $B$. sacchari IPT $101 \mathrm{~A}$ and $B$. cepacia IPT 048, respectively, with a CDW of $4.4 \mathrm{~g} \mathrm{l}^{-1}$ for both strains under $\mathrm{N}$ limitation (Table 3).

Yu and Stahl [22] also studied the performance of $C$. necator with the same substrate. In their experiment, the cultures were shaken in flasks at $200 \mathrm{rpm}$ and $30{ }^{\circ} \mathrm{C}$ for $48 \mathrm{~h}$ with $\mathrm{pH}$ adjusted to approximately 7.5. They demonstrated that $\mathrm{P}(3 \mathrm{HB})$ was the predominant biopolyester formed from the hydrolysis of sugarcane bagasse, with a concentration of $3.9 \mathrm{~g} \mathrm{l}^{-1}$, corresponding to a $\mathrm{P}(3 \mathrm{HB})$ accumulation of $65 \%$ of the CDW, achieved with a high carbon-to-nitrogen ratio ( $C / N=20$ or above). Since a minimum nitrogen level should be maintained during cultivation, this high $C / N$ ratio implies a high concentration of residual organic carbon or a high amount of hydrolysates. A moderate $C / N$ ratio (7-10) may be used to yield a low concentration (less than $1 \mathrm{~g} \mathrm{l}^{-1}$ ) of residual carbons and a moderate level of PHA content in the cells $(45-50 \% \mathrm{w} / \mathrm{w})$.
Lee et al. [69] investigated $\mathrm{P}(3 \mathrm{HB})$ production from xylose and hydrolyzed cellulose by growing recombinant $E$. coli strains with $C$. necator PHA biosynthesis genes, testing the effects of supplementing a complex nitrogen source on cell growth and PHB production. The cells were cultivated for $60 \mathrm{~h}$ in a 250-ml flask containing $50 \mathrm{ml}$ of medium in a shaking incubator at $250 \mathrm{rpm}$. When the strain TG1 (pSYL107) was grown on $20 \mathrm{~g} \mathrm{l}^{-1}$ xylose, it was capable of accumulating $1.7 \mathrm{~g} \mathrm{l}^{-1}$ of $\mathrm{P}(3 \mathrm{HB})$ with $35.8 \%$ of polymer content. A higher $\mathrm{P}(3 \mathrm{HB})$ concentration, equal to $4.4 \mathrm{~g} \mathrm{l}^{-1}$, and a polymer content of $73.9 \%$ were reached when the previous culture medium was supplemented with $10 \mathrm{~g} \mathrm{l}^{-1}$ of soybean hydrolysate. To evaluate the effects of the nitrogen source, tryptone and peptone were also tested, achieving 47.7 and $10.3 \%$ of PHB content, respectively.

The ability of R. eutropha ATCC 17699 (C. necator) to produce $\mathrm{PHB}$ in the presence of different waste biomass hydrolysates (rice paddy straw, soybean husk, sunflower husk, and wood straw) was evaluated by Saratale and Oh [79]. The most suitable substrate for PHB accumulation by this strain was the rice paddy straw hydrolysate, which was selected by the authors for optimization of the process, obtaining the maximal PHA accumulation (75.45\%) and PHB production (11.42 $\mathrm{g} \mathrm{l}^{-1}$ ) within $48 \mathrm{~h}$ of fermentation.

Moreover, lignin and its derivatives are also used for PHA production. Tomizawa et al. [80] tested PHA-accumulating strains on mineral salt media containing each of the 18 lignin derivatives and hydroxybenzoic acids, including intermediates derived from the metabolism of lignin derivatives in bacteria. Most of the strains grew poorly in media containing lignin derivatives, such as p-coumaric acid, caffeic acid, ferulic acid, and sinapinic acid.

On the contrary, $R$. eutropha PHB-4 accumulated $\mathrm{P}(3 \mathrm{HB})$ from 3-hydroxybenzoic acid and 4-hydroxybenzoic acid as the sole carbon sources, with a PHA content of 65 and $63 \mathrm{wt} \%$ and a dry cell weight of 1.6 and $0.69 \mathrm{~g} \mathrm{l}^{-1}$, respectively.

Although C. necator species seems to be the best bacterial candidate for $\mathrm{PHB}$ production using lignocellulosic

Table 3 Overview of studies reporting PHA production from lignocellulosic materials

\begin{tabular}{|c|c|c|c|c|c|c|}
\hline Strain & Type of PHA & Operation mode & Time to $\mathrm{PHA}_{\max }[\mathrm{h}]$ & PHA concentration $\left[\mathrm{g} \mathrm{I}^{-1}\right]$ & PHA content [\%] & References \\
\hline Burkholderia sacchari IPT 101 & $\mathrm{P}(3 \mathrm{HB})$ & Batch & 25 & 2.73 & 62 & {$[46]$} \\
\hline Burkholderia cepacia IPT 048 & $P(3 \mathrm{HB})$ & Batch & 25 & 2.33 & 53 & [46] \\
\hline Cupriavidus necator & PHA & Batch & 48 & 3.9 & 65 & [22] \\
\hline \multirow{2}{*}{$\begin{array}{l}\text { Recombinant E. coli (C. necator } \\
\text { genes) }\end{array}$} & \multirow[t]{2}{*}{$\mathrm{P}(3 \mathrm{HB})$} & \multirow[t]{2}{*}{ Batch } & 60 & 1.7 & 35.8 & \multirow[t]{2}{*}{ [69] } \\
\hline & & & 60 & 4.4 & 73.9 & \\
\hline $\begin{array}{l}\text { R. eutropha ATCC } 17699 \text { (C. } \\
\text { necator) }\end{array}$ & $\mathrm{P}(3 \mathrm{HB})$ & Batch & 48 & 11.4 & 75.5 & [79] \\
\hline
\end{tabular}


hydrolysate, the accumulation is lower than that obtained with sucrose- and starch-based materials as carbon sources. The lowest PHA accumulation could be due to the presence of specific toxic compounds (e.g., furfural, HMF, $p$-hydroxybenzoic aldehyde, and vaniline) that are usually released during the pretreatment of lignocellulosic biomass, which are known to have an inhibitory effect on microbial growth and metabolism.

\section{Whey-based culture media as a source for producing PHAs} Whey is the major by-product of cheese factories, representing $80-90 \%$ of the volume of transformed milk [42]. It contains approximately $4.5 \%(\mathrm{w} / \mathrm{v})$ lactose, $0.8 \%(\mathrm{w} / \mathrm{v})$ protein, $1 \%(\mathrm{w} / \mathrm{v})$ salts, and $0.1-0.8 \%(\mathrm{w} / \mathrm{v})$ lactic acid, and its high biological oxygen demand $\left(40 \mathrm{~g} \mathrm{l}^{-1}\right)$ makes it difficult to dispose. The discharge of large amounts of cheese whey into the environment can damage the chemical and physical structure of soil and pollute groundwater and can also affect the air [81]. This by-product represents an attractive low-cost substrate for producing PHAs.

As seen in the previous sections, $C$. necator is one of the best-known bacteria among PHA-producing microorganisms, but it is unable to hydrolyze lactose or metabolize galactose [82]. In fact, C. necator was able to use lactose only after the expression of genes encoding $\beta$-galactosidase and galactokinase, although at a very slow rate [83]. Therefore, recombinant $E$. coli containing the $C$. necator PHA biosynthesis genes for the production of PHB from glucose is considered a good candidate for PHB production from whey [42]. Lee et al. [42] cultivated recombinant $E$. coli strains in a defined medium supplemented with varying concentrations of whey solution and obtained $5.2 \mathrm{~g} \mathrm{l}^{-1}$ of PHB, corresponding to $81.3 \%(\mathrm{w} / \mathrm{w})$ of PHB, with a concentration of $30 \mathrm{~g} \mathrm{l}^{-1}$ of whey solution (Table 4). Kim [35] also studied recombinant $E$. coli strains as PHB-accumulating microorganisms under $\mathrm{O}_{2}$ limitation compared with conditions without $\mathrm{O}_{2}$ limitation. The highest PHB accumulation (80\%) was observed under $\mathrm{O}_{2}$-limiting conditions, with a PHB concentration of $25 \mathrm{~g} \mathrm{l}^{-1}$. Instead, without $\mathrm{O}_{2}$ limitation, 57\% of PHB was achieved with a concentration of $32 \mathrm{~g} \mathrm{l}^{-1}$. A recombinant $E$. coli strain containing the PHA biosynthetic genes from Azotobacter spp., specially designed for the production of PHB from milk whey, was studied by Nikel et al. [43]. Fed-batch cultures were carried out at $37^{\circ} \mathrm{C}$ in a 5.6-1 fermentor with a starting volume of $2.0 \mathrm{l}$ and a controlled $\mathrm{pH}$ of 7.20. The feeding solution used for fed-batch cultures was a concentrated and deproteinated whey solution containing $25 \%(\mathrm{w} / \mathrm{v})$ lactose. They reported that after $24 \mathrm{~h}$, the cells accumulated PHB up to $72.9 \%$ of their cell dry weight, reaching a PHA concentration of $51.1 \mathrm{~g} \mathrm{l}^{-1}$. Physical analysis of PHB collected from the recombinants showed that its molecular weight was similar to PHB produced by an Azotobacter spp. strain.

A new fermentation strategy using a cell recycle membrane system was developed by Ahn et al. [12] for the efficient production of $\mathrm{P}(3 \mathrm{HB})$ from whey by a recombinant $E$. coli strain harboring the Alcaligenes latus PHA biosynthesis genes.

Cell fed-batch cultures of recombinant E. coli CGSC 4401 (pJC4) were carried out to overcome the volumetric limitation of a fermentor $(2.7 \mathrm{l})$ fed with a solution with low lactose solubility to increase PHB productivity. A whey solution containing $210 \mathrm{~g}$ lactose $\mathrm{l}^{-1}$ was used as a

Table 4 Overview of studies reporting PHA production from whey-based culture media

\begin{tabular}{|c|c|c|c|c|c|c|}
\hline Strain & Type of PHA & Operation mode & Time to $\mathrm{PHA}_{\max }[\mathrm{h}]$ & $\begin{array}{l}\text { PHA concentration } \\
{\left[\mathrm{g} \mathrm{I}^{-1}\right]}\end{array}$ & PHA content [\%] & References \\
\hline $\begin{array}{l}\text { Recombinant } E \text {. coli ( } C \text {. } \\
\text { necator genes) }\end{array}$ & $\mathrm{P}(3 \mathrm{HB})$ & Batch & 49 & 5.2 & 81.3 & {$[42]$} \\
\hline \multirow{2}{*}{$\begin{array}{l}\text { Recombinant E. coli (C. } \\
\text { necator genes) GCSC } \\
6576\end{array}$} & \multirow[t]{2}{*}{$\mathrm{P}(3 \mathrm{HB})$} & $\begin{array}{l}\text { Fed-batch with oxygen } \\
\text { limitation }\end{array}$ & 52 & 25 & 80 & {$[35]$} \\
\hline & & $\begin{array}{l}\text { Fed-batch without } \\
\text { oxygen limitation }\end{array}$ & 35 & 32 & 57 & \\
\hline \multirow{2}{*}{$\begin{array}{l}\text { Pseudomonas hydrog- } \\
\text { enovora DSM } 1749\end{array}$} & $\mathrm{P}(3 \mathrm{HB})$ & \multirow[t]{2}{*}{ Fed-batch } & 41 & 1.27 & 12 & \multirow[t]{2}{*}{ [29] } \\
\hline & $\mathrm{P}(3 \mathrm{HB}-\mathrm{CO}-3 \mathrm{HV})$ & & 31 & 1.44 & 12 & \\
\hline $\begin{array}{l}\text { Recombinant E. coli } \\
\text { K24 K (Azotobacter spp. } \\
\text { genes) }\end{array}$ & $\mathrm{P}(3 \mathrm{HB})$ & Fed-batch & 24 & 51.1 & 72.9 & {$[43]$} \\
\hline $\begin{array}{l}\text { Recombinant E. coli } \\
\text { CGSC } 4401\end{array}$ & $P(3 H B)$ & Fed-batch & 36.5 & 96.2 & 80.5 & {$[12]$} \\
\hline \multirow{2}{*}{$\begin{array}{l}\text { Recombinant E. coli } \\
\text { CGSC } 4401 \text { (A. latus } \\
\text { genes) }\end{array}$} & \multirow[t]{2}{*}{$\mathrm{P}(3 \mathrm{HB})$} & $\begin{array}{l}\text { Fed-batch 30-I bioreac- } \\
\text { tor }\end{array}$ & 26 & 35.5 & 70 & \multirow[t]{2}{*}[44]{} \\
\hline & & $\begin{array}{l}\text { Fed-batch 300-I bioreac- } \\
\text { tor }\end{array}$ & 20 & 20 & 67 & \\
\hline
\end{tabular}


feeding solution. The final cell concentration, PHB concentration, and PHB content obtained in $39 \mathrm{~h}$ were 150 , $100 \mathrm{~g} \mathrm{l}^{-1}$, and $67 \%$, respectively. In another experiment, a whey solution containing 280 g lactose $\mathrm{l}^{-1}$ was used as a feeding solution. After $36.5 \mathrm{~h}$, a PHB concentration and a PHB content of $96.2 \mathrm{~g} \mathrm{l}^{-1}$ and $80.5 \%$, respectively, were obtained using a whey solution concentrated to contain $280 \mathrm{~g}$ lactose $1^{-1}$ as a feeding medium. No inhibitory effects of the by-products or nutrients on cell growth and PHB production were found during fermentation by the authors.

The production of $\mathrm{P}(3 \mathrm{HB})$ from whey by fed-batch cultures of recombinant $E$. coli harboring a plasmid containing the Alcaligenes latus PHA biosynthesis genes was examined by Park et al. [44]. Fed-batch cultures of recombinant $E$. coli SGSC 4401 (pJC4) were carried out at $30{ }^{\circ} \mathrm{C}$ in $30 \mathrm{l}$ (working volume of $10 \mathrm{l}$ ) and $300 \mathrm{l}$ (working volume of $150 \mathrm{l}$ ) fermenters supplying only air. The culture $\mathrm{pH}$ was controlled at 6.9. With lactose below $2 \mathrm{~g} \mathrm{l}^{-1}$, the cells grew to $12 \mathrm{~g} \mathrm{l}^{-1}$ with $9 \%(\mathrm{w} / \mathrm{w}) \mathrm{P}(3 \mathrm{HB})$ content in a $30 \mathrm{l}$ fermenter. The accumulation of $\mathrm{P}(3 \mathrm{HB})$ could be triggered by increasing lactose to $20 \mathrm{~g} \mathrm{l}^{-1}$. Using this strategy, $35.5 \mathrm{gl}^{-1}$ was obtained with a $70 \%(\mathrm{w} / \mathrm{w}) \mathrm{P}(3 \mathrm{HB})$ content after $26 \mathrm{~h}$. The same fermentation strategy was used in a $300 \mathrm{l}$ fermenter, and a $20 \mathrm{~g} \mathrm{l}^{-1}$ with $67 \%(\mathrm{w} / \mathrm{w})$ $\mathrm{P}(3 \mathrm{HB})$ content was obtained in $20 \mathrm{~h}$ by Park et al. [44]. Koller et al. [29] compared the production of PHB under nitrogen-limiting conditions obtained with $P$. hydrogenovora using the following two substrates: hydrolyzed whey permeate and glucose/galactose medium. Shake flasks (1 l) containing $250 \mathrm{ml}$ of hydrolyzed whey permeate or synthetic medium supplemented with glucose and galactose (each $2.5 \mathrm{~g} \mathrm{l}^{-1}$ ) were both inoculated with $5 \%(\mathrm{v} / \mathrm{v}) P$. hydrogenovora. The flasks were shaken at $30{ }^{\circ} \mathrm{C}$ for $48 \mathrm{~h}$. Furthermore, the study investigated the influence of the $3 \mathrm{HV}$ precursor sodium valerate on the bacterial growth of $P$. hydrogenovora. Thanks to its advanced properties compared with those of highly crystalline pure PHB [29], the ability of the strain to biosynthesize $\mathrm{P}(3 \mathrm{HB}-\mathrm{co}-3 \mathrm{HV})$ in media supplemented with hydrolyzed whey permeate and sodium valerate was evaluated. In these two different experiments, PHA content was confirmed at $12 \%$ for both types of PHAs, but the PHA concentration was higher when sodium valerate was added to $\mathrm{P}(3 \mathrm{HB}-\mathrm{co}-$ $3 \mathrm{HV}$ ) production (Table 4).

A recombinant strain of $E$. coli was generally used to obtain the PHA concentration (more than $90 \mathrm{~g} \mathrm{l}^{-1}$ ) from whey-based culture media because $C$. necator is unable to hydrolyze lactose. In fact, several studies tested different lactose concentrations to correlate this parameter to PHA accumulation. Fed-batch experiments supplemented with a high amount of lactose (hydrolyzed from chees whey) were performed to obtain a higher PHA concentration. Otherwise, when increasing the lactose concentration to $280 \mathrm{~g} \mathrm{l}^{-1}$, a relevant increase in PHA concentration was not observed.

In addition, it is interesting to note that with wheybased culture media, the oxygen-limiting conditions enhance PHB biosynthesis from recombinant $E$. coli but decrease PHA concentration in the cells.

\section{Fatty acid and glycerol culture media as source for PHAs}

Pure glycerol is an important industrial feedstock, with applications in the food, drug, cosmetic, and tobacco industries, while crude glycerol is the main by-product of biodiesel production, with low value due to the presence of impurities (such as methanol, salts, and fatty acids). Thus, crude glycerol represents a waste product with an associated disposal cost [10]. For this reason, it can be used as an attractive substrate for PHA production.

Cupriavidus necator DSM 545 was used by Cavalheiro et al. [10] to accumulate $\mathrm{P}(3 \mathrm{HB})$ from waste glycerol and from commercial glycerol as a control substrate. For $C$. necator cultivated on basal medium supplemented with pure glycerol and nitrogen depletion, a maximum of $51.2 \mathrm{~g} \mathrm{l}^{-1}$ of $\mathrm{P}(3 \mathrm{HB})$ at $33.5 \mathrm{~h}$ was reached, with a PHB content of $62 \%$ (Table 5). On the contrary, using waste glycerol as a carbon source, productivity was lower because only $38.5 \mathrm{~g} \mathrm{l}^{-1}$ was achieved with a PHB content of $50 \%$ in $34.5 \mathrm{~h}$.

Production of PHAs from various plant oils or oleic acid by $C$. necator H16 was studied by Fukui and Doi [23]. The strain was tested on olive oil, corn oil, and palm oil and in all these plant oils. The strain was cultivated in a 100 -ml nitrogen-limited mineral salt medium containing $1 \%$ plant oil at $30{ }^{\circ} \mathrm{C}$ for $72 \mathrm{~h}$. The wild-type strain

Table 5 Overview of studies reporting PHA production from oil, fatty acid, and glycerol culture media

\begin{tabular}{|c|c|c|c|c|c|c|}
\hline Strain & Type of PHA & Operation mode & Time to $\mathrm{PHA}_{\max }[\mathrm{h}]$ & PHA concentration $\left[\mathrm{g} \mathrm{I}^{-1}\right]$ & PHA content [\%] & References \\
\hline C. necator DSM 545 & $\mathrm{P}(3 \mathrm{HB})$ & Fed-batch & 33.5 & 51.2 & 62 & [10] \\
\hline C. necator H16 (ATCC 17699) & $\mathrm{P}(3 \mathrm{HB})$ & Batch & 72 & $2.9-3.4$ & $79-82$ & {$[23]$} \\
\hline C. necator H16 (pJRDEE32d13) & $\mathrm{P}(3 \mathrm{HB})$ & Fed-batch & 96 & $85-95$ & $72-76$ & {$[24]$} \\
\hline C. necator $\mathrm{H} 16$ & $\mathrm{P}(3 \mathrm{HB})$ & Batch & 96 & 1.24 & 19.7 & {$[25]$} \\
\hline Pseudomonas resinovorans & $\mathrm{PHA}$ & Batch & 48 & 0.14 & 15.2 & [30] \\
\hline
\end{tabular}


produced $\mathrm{P}(3 \mathrm{HB})$ at a high polymer content (79-82\%) but at low concentrations $\left(2.9-3.4 \mathrm{~g} \mathrm{l}^{-1}\right)$.

Kahar et al. [24] produced a copolymer of $3 \mathrm{HB}$ with 5 mol\% (R)-3-hydroxyhexanoate, $\mathrm{P}$ (3HB-co-3HHx), from soybean oil as a sole carbon source with a recombinant strain of $C$. necator. The medium for PHA production in the fermentor was a mineral salt medium, and the initial concentration of $\mathrm{NH}_{4} \mathrm{Cl}$ was set at $4 \mathrm{~g} \mathrm{l}^{-1}$. Additional $\mathrm{NH}_{4} \mathrm{Cl}$ was intermittently fed into the culture broth to avoid nitrogen source depletion. Soybean oil was added to the fermentor for an initial concentration of $20 \mathrm{~g} \mathrm{l}^{-1}$. A high content of $\mathrm{P}(3 \mathrm{HB})\left(85-95 \mathrm{~g} \mathrm{l}^{-1}\right)$ and a high PHA content of $71-74 \%(\mathrm{w} / \mathrm{w})$ were achieved during $96 \mathrm{~h}$.

Füchtenbusch et al. [25] studied $R$. eutropha and $P$. oleovorans cultivated in a mineral salt medium with the oil from rhamnose production as the sole carbon source under aerobic conditions at $30{ }^{\circ} \mathrm{C}$ in nutrient broth or in mineral salt medium.

The concentration of ammonium was limited to $0.05 \%$ $(\mathrm{m} / \mathrm{v})$ to promote the accumulation of PHAs. The cultivation of $P$. oleovorans and $R$. eutropha was performed in $300 \mathrm{ml}$ at $28^{\circ} \mathrm{C}$. C. necator accumulated only $\mathrm{P}(3 \mathrm{HB})$ at $6.3 \mathrm{~g} \mathrm{l}^{-1}$, with a polyester content of $19.7 \%$ during the first $96 \mathrm{~h}$ (Table 5). The same authors tested P. oleovorans under the same operating conditions using the same carbon source. After $96 \mathrm{~h}$, this strain accumulated $5 \mathrm{~g} \mathrm{l}^{-1}$, with a $\mathrm{P}(3 \mathrm{HB}-\mathrm{co}-3 \mathrm{HHx})$ content of $17.3 \%$.

Different Pseudomonas species (P. oleovorans, P. resinovorans, $P$. putida, and $P$. citronellolis) were tested by Cromwick et al. [30] in 2-1 shake flasks. The bacteria were evaluated for their ability to grow and produce PHAs using tallow-free fatty acids and tallow triglyceride as carbon substrates; however, only $P$. resinovorans was able to grow and produce PHAs. The PHA concentration in this case was $0.12-0.15 \mathrm{~g} \mathrm{l}^{-1}$, with a $15.2 \%$ polymer content, using unhydrolyzed tallow as the substrate.

The different fatty acids and glycerol waste materials used as substrates for PHA accumulation highlighted that $C$. necator was the best candidate operating under nitrogen source depletion, although PHA accumulation depended on the strain and operating mode. In fact, performing the experiments in fed-batch mode, more PHB was accumulated in the cells than operating in batch mode.

\section{Solid agro-industrial by-products and waste as a source of PHA production}

Law et al. [40] showed that recombinant B. subtilis could utilize malt waste in the medium as a carbon source better than glucose and thus could substantially lower the cost of PHA production. In the paper by Law and coauthors, the pha genes (involved into PHA accumulation) from B. megaterium were cloned into B. subtilis.
The recombinant strain was cultivated by acid hydrolyzed malt waste, and a $1 \%$ inoculum was used in a fermentation flask incubated at $37{ }^{\circ} \mathrm{C}$ at $280 \mathrm{rpm}$ for $16 \mathrm{~h}$. Their results showed PHA accumulation in a malt waste medium of $2.53 \%$ with a PHB concentration of $0.06 \mathrm{~g} \mathrm{l}^{-1}$ in $12 \mathrm{~h}$ (Table 6).

Aztoobacter vinelandii UWD strains were tested by Cho et al. [34] with most poly-3-hydroxybutyrate-covalerate (PHBV) production from swine waste liquor. Strain UWD was cultured in a shake flask with $4 \%$ inoculum at $200 \mathrm{rpm}$, incubated at $30^{\circ} \mathrm{C}$ for $18-52 \mathrm{~h}$.

Using undiluted swine waste liquor medium without glucose supplementation, cell growth was limited to $1.2 \mathrm{~g} \mathrm{l}^{-1}$ with $37 \%$ in $48 \mathrm{~h}$. Cell growth and PHBV production increased when swine waste liquor was diluted twofold and supplemented with $30 \mathrm{~g}$ glucose $\mathrm{l}^{-1}\left(5.48 \mathrm{~g} \mathrm{l}^{-1}\right.$ and PHBV content 58\%).

Industrial fruit and vegetable waste were successfully used as sole carbon sources by Ganzeveld et al. [84] to produce PHBV by $R$. eutrophus under oxygen-limiting conditions. The fermentor was a 1-1 standard fermentor with a working volume of $750 \mathrm{ml}$. The temperature was controlled at $30^{\circ} \mathrm{C}$. The stirrer speed was adjusted manually to maintain the dissolved oxygen pressure above $30 \%$ of the saturation concentration. A concentration of $1.1 \mathrm{~g} \mathrm{PHBV}^{-1}$, or $40 \%(\mathrm{w} / \mathrm{w})$ of the cell dry weight, was obtained.

Starchy wastewater was used by Yu [26]. The waste was first digested in a thermophilic upflow anaerobic sludge blanket (UASB) reactor to form acetic, propionic, and butyric acids. PHA formation from individual acids was further investigated under nitrogen-limiting conditions by active biomass of $R$. eutropha. PHA formation from acid effluent in $48 \mathrm{~h}$ was $1.2 \mathrm{~g} \mathrm{l}^{-1}$, with a PHA content of $34.1 \%$ (Table 6).

Another suitable substrate for PHA production is food scraps, a complex form of organic solid waste that is unusable by PHA-producing microbes, such as $R$. eutropha. Hydrolysis and acidogenesis are the main processes used to convert biodegradable solids into short-chain volatile fatty acids, such as acetic, propionic, and butyric acids, which are utilized by PHAproducing bacteria. This approach was used by Du et al. [85] by coupling organic acid production with anaerobic acetogenesis to produce PHAs. The PHA-synthesis reactor (2-1 air-bubbling bioreactor) was maintained at $30{ }^{\circ} \mathrm{C}$ via a water jacket and $\mathrm{pH}$ 7.5. The dissolved oxygen concentration was maintained at $20 \%$ of air saturation or above. The PHA content and concentration reached their maximal values of $72.6 \%$ and $16.5 \mathrm{~g} \mathrm{l}^{-1}$, respectively, in $73 \mathrm{~h}$.

Other studies were conducted on the use of excess activated sludge from a wastewater treatment plant fed with 
Table 6 Overview of studies reporting PHA production from solid agro-industrial by-products

\begin{tabular}{|c|c|c|c|c|c|c|}
\hline Strain & Type of PHA & Operation mode & Time to $\mathrm{PHA}_{\max }[\mathrm{h}]$ & PHA concentration $\left[\mathrm{g} \mathrm{I}^{-1}\right]$ & PHA content [\%] & References \\
\hline $\begin{array}{l}\text { Recombinant Bacillus subtilis } \\
\text { 1A304 (105 MU331) }\end{array}$ & $\mathrm{P}(3 \mathrm{HB})$ & Batch & 12 & 0.06 & 2.5 & [40] \\
\hline \multirow{2}{*}{$\begin{array}{l}\text { Azotobacter vinelandii UWD } \\
\text { (ATCC 53799) }\end{array}$} & \multirow[t]{2}{*}{$\mathrm{P}(3 \mathrm{HB}-\mathrm{co}-3 \mathrm{HV})$} & \multirow[t]{2}{*}{ Batch } & 48 & 0.43 & 37 & \multirow[t]{2}{*}{ [34] } \\
\hline & & & 18 & 5.48 & 58.3 & \\
\hline \multirow[t]{3}{*}{ C. necator (R. eutropha) } & \multirow[t]{3}{*}{$\mathrm{P}(3 \mathrm{HB}-\mathrm{CO}-3 \mathrm{HV})$} & Batch & 45 & 1.13 & 40.8 & [84] \\
\hline & & Batch & 48 & 1.2 & 34.1 & [26] \\
\hline & & Fed-batch & 73 & 16.5 & 72.6 & [85] \\
\hline Activated sludge & $\mathrm{P}(3 \mathrm{HB})$ & Batch & 96 & 2.7 & 67 & [87] \\
\hline
\end{tabular}

industrial waste streams as a substrate for PHB accumulation [86]. Wastewater from food processing (producing mainly potato chips, wafers, and sweets) and starch-rich grain-based alcohol industries (rice grain-based and jowar grain-based distillery spent wash) was used as a substrate for PHB production by Khardenavis et al. [87]. In their work, different types of wastewater were tested in $250-\mathrm{ml}$ conical flasks and incubated on a rotary shaker at $150 \mathrm{rpm}$ at $30{ }^{\circ} \mathrm{C}$ : wastewater derived directly from industry, filtered wastewater, and deproteinized wastewater, each in the absence and presence of an external nitrogen source; the highest biomass concentration of $6.6 \mathrm{~g} \mathrm{l}^{-1}$ (dry weight) was produced in $96 \mathrm{~h}$ in a raw rice grain-based distillery spent wash with the addition of di-ammonium hydrogen phosphate, accumulating $2.7 \mathrm{~g} \mathrm{l}^{-1} \mathrm{PHB}$ with a content of $67 \%$; a deproteinized jowar grain-based distillery spent wash and filtered food processing wastewater yielded lower PHB and biomass accumulation.

The studies carried out using solid agro-industrial byproducts and waste demonstrated that the accumulation of PHAs was lower than that obtained with the other complex starting matrices, which was also observed when lignocellulosic hydrolysates were used as carbon sources. In addition, with this organic biomass, the highest accumulation was achieved using $C$. necator species, although the operating mode strongly influenced the process. Interestingly, activated sludge from a wastewater treatment plant was used as mixed cultures for PHA production from industrial waste streams. In particular, the PHA concentration was similar to that observed with pure cultures, overcoming the high costs derived from the production of pure cultures and the disposal of waste activated sludge.

\section{Integrated systems to simultaneously produce intracellular (PHAs) and extracellular by-products (biosurfactants)}

Bacterial strains actively involved in PHA accumulation can be used at industrial scale to reduce the production costs of biopolymers due to their ability to convert waste materials into valuable intracellular and extracellular bi-products (e.g., PHAs and exopolysaccharides (EPS), respectively) that are useful for biochemical production. PHAs represent intracellular carbon and energy storage, while EPS and biosurfactants are produced as extracellular substances to protect the cells from desiccation and predation or are a carbon source. These substances are of industrial interest for washing powders and fabric softener production [88]. They are used also in the food, chemical, cosmetic, and packaging industries as adhesives, absorbents, lubricants, and cosmetics [89-91].

Biosurfactants are amphipathic molecules with polar and non-polar heads produced by different bacterial genera (e.g., Acinetobacter, Arthrobacter, Bacillus, Pseudomonas, Rhodococcus, and Enterobacter) [92]. Biosurfactants present as a wide variety of structures because their synthesis is influenced by the carbon source [93]. In fact, they can be produced on different substrates, such as sugars, lipids, alkanes, and waste materials [92]. The main property of biosurfactants is the ability to reduce surface and interfacial tension, forming microemulsions [94]. Among biosurfactants, rhamnolipids are the most studied thanks to the simultaneous production of PHAs and rhamnolipids by $P$. aeruginosa IFO3924 [31]. In their work, batch cultivation was conducted at $30{ }^{\circ} \mathrm{C}$ in 3-1 fermentors equipped with an agitator using $7 \mathrm{~g} \mathrm{l}^{-1}$ of decanoate as a carbon source. In this experiment, basal salt medium was used to increase the concentration of the nitrogen source. After a 3-day cultivation, considerable PHA content (23\% of CDW corresponding to a concentration of $2.2 \mathrm{~g} \mathrm{l}^{-1}$ ) and rhamnolipid amounts (298 $\left.\mathrm{mg} \mathrm{l}^{-1}\right)$ were produced.

Another type of extracellular polymeric substance is EPS, a mixture of high molecular polymers, which supplies carbon units when substrate is limited. Wang and $\mathrm{Yu}$ [27] studied the simultaneous biosynthesis of EPS (an extracellular product) and PHB (an intracellular product) by $R$. eutropha. They observed that EPS production was closely coupled with cell growth, while PHB was synthesized only under nitrogen-limiting conditions and 
cell growth-limiting conditions. In fact, the experiments were conducted at different concentrations of glucose and $\mathrm{NH}_{4}-\mathrm{N}$ to evaluate their influence on EPS and PHB production. Furthermore, the previous authors observed that the PHB content in dry cells decreased with increasing nitrogen concentration, while the EPS concentration increased. While keeping the nitrogen concentration constant, further experiments were conducted at varying glucose concentrations, and the results showed that an increase in glucose concentration promoted biomass growth and PHB production. The relevant production (shown in Table 7) of both polymers was observed when glucose and nitrogen were supplied at concentrations of 40 and $3 \mathrm{~g} \mathrm{l}^{-1}$, respectively.

Among EPS, alginates are of great commercial interest for their use in a wide range of applications in the food industry, such as in frozen custards, restructured foods, cream and cake mixtures, and beer production. They are composed of variable amounts of $\beta$-Dmannuronic acid and C5-epimer $\alpha$-L-guluronic acid linked via $\beta-1,4$-glycosidic bonds. When extracting alginates from harvested material, the uronic acids are converted into the salt forms mannuronate and guluronate through a neutralization step. The proportion, distribution, and length of these blocks determine the chemical and physical properties of the alginate molecules. Commercial alginates are currently extracted from marine algae, such as Laminaria and Macrocystis, but can also be obtained from bacterial species, such as $A$. vinelandii, $P$. aeruginosa, and $P$. mendocina [31]. The co-production of alginates and PHAs by $P$. mendocina using glucose as a carbon source was studied by Guo et al. [32]. The simultaneous production of MCL-PHA and alginate oligosaccharide $(\mathrm{AO})$ cultivation was performed in $200 \mathrm{l}$ fermenters with $120 \mathrm{l}$ mineral salt medium containing $20 \mathrm{~g} \mathrm{l}^{-1}$ glucose at $30{ }^{\circ} \mathrm{C}$ and $200 \mathrm{rpm}$ of impeller speed for $48 \mathrm{~h}$. The authors reported that $0.316 \mathrm{~g} \mathrm{l}^{-1}$ $\mathrm{PHA}_{\mathrm{MCL}}$ and $0.57 \mathrm{~g} \mathrm{l}^{-1} \mathrm{AO}$ were obtained at the end of the fermentation process. The MCL-PHA production reached a maximum of $0.360 \mathrm{~g} \mathrm{l}^{-1}$ at $36 \mathrm{~h}$ when the carbon source was almost exhausted. At $48 \mathrm{~h}$, the utilization of intracellular stored MCL-PHA took place, corresponding to a decrease in PHA content to $0.316 \mathrm{~g}^{-1}$.

Moreover, the production of PHB and EPS by A. beijerinckii was investigated by Pal et al. [37] under nitrogenfree conditions with an excess of carbon. This strain was maintained by growth on nitrogen-free glucose medium at $30{ }^{\circ} \mathrm{C}$ for $48 \mathrm{~h}$ and was then stored at $4{ }^{\circ} \mathrm{C}$. Nitrogenfree liquid medium was inoculated with $4 \%(\mathrm{v} / \mathrm{v})$ inoculum, and the flasks were incubated at $30{ }^{\circ} \mathrm{C}$ on a rotary shaker. The highest production of PHB $\left(2.73 \mathrm{~g} \mathrm{l}^{-1}\right)$ was reached when glucose was supplemented at $3 \%(\mathrm{w} / \mathrm{v})$, observing an EPS amount of $1.2 \mathrm{~g} \mathrm{l}^{-1}$.

Quagliano and Miyazaki [36] studied the simultaneous production of PHB and EPS by A. chroococcum, evaluating the influence of ammonium addition with glucose, fructose, and sucrose. The organism was grown aerobically in 250- and 500-ml flasks at a one-third volume of the culture medium with the carbon sources alone or supplemented with $0.1 \mathrm{~g} \mathrm{l}^{-1}$ of $\left(\mathrm{NH}_{4}\right)_{2} \mathrm{SO}_{4}$. The flasks were incubated in a rotatory shaker at $220 \mathrm{rpm}$ at $30{ }^{\circ} \mathrm{C}$ for $72 \mathrm{~h}$.

The highest PHB content was obtained with sucrose $\left(1.1 \mathrm{~g} \mathrm{l}^{-1}\right)$, but EPS production was almost unobservable. Instead, the experiments conducted with glucose showed a maximum EPS concentration $\left(2.1 \mathrm{~g} \mathrm{l}^{-1}\right)$, with PHB production of $0.74 \mathrm{~g} \mathrm{l}^{-1}$.

Thus, some microorganisms, such as $P$. aeruginosa, $R$. eutropha, A. beijerinckii, A. chroococcum, and P. mendocina, are able to concurrently produce PHAs and biosurfactants using the same type of organic substrate. However, the bacterial technological performance during the coupled process of PHA and biosurfactant production leads to a lower accumulation of PHAs. In particular, the optimal operating conditions for PHA and biosurfactant production are different. In fact, Wang and $\mathrm{Yu}$

Table 7 Overview of studies reporting PHA production coupled to metabolites used in industry

\begin{tabular}{|c|c|c|c|c|c|c|c|}
\hline Strain & $\begin{array}{l}\text { Type } \\
\text { of PHA }\end{array}$ & $\begin{array}{l}\text { Operation } \\
\text { mode }\end{array}$ & $\begin{array}{l}\text { Time } \\
\text { to } \mathrm{PHA}_{\max } \\
{[\mathrm{h}]}\end{array}$ & $\begin{array}{l}\text { PHA concentration } \\
{\left[\mathrm{g} \mathrm{l}^{-1}\right]}\end{array}$ & $\begin{array}{l}\text { PHA content } \\
{[\%]}\end{array}$ & $\begin{array}{l}\text { Produced } \\
\text { metabolites }\left[\mathrm{g} \mathrm{I}^{-1}\right]\end{array}$ & References \\
\hline $\begin{array}{l}\text { Pseudomonas aeruginosa } \\
\text { IFO3924 }\end{array}$ & $\mathrm{PHA}$ & Batch & 72 & 0.5 & 23 & Rhamnolipids 0.3 & [31] \\
\hline $\begin{array}{l}\text { Ralstonia eutropha ATCC } \\
\quad 17699\end{array}$ & PHB & Batch & 60 & 12.7 & 62 & EPS 0.18 & {$[27]$} \\
\hline $\begin{array}{l}\text { Azotobacter beijerinckii } \\
\text { WDN-01 }\end{array}$ & PHB & Batch & 40 & 2.73 & 54.6 & EPS 1.2 & [37] \\
\hline $\begin{array}{l}\text { Azotobacter chroococcum } \\
6 \mathrm{~B}\end{array}$ & PHB & Batch & 48 & 0.74 & 28 & EPS 2.1 & [36] \\
\hline $\begin{array}{l}\text { Pseudomonas mendocina } \\
\text { NK-01 }\end{array}$ & $\mathrm{PHA}_{\mathrm{MCL}}$ & Batch & 48 & 0.316 & 25.3 & $\begin{array}{l}\text { Alginate oligosaccha- } \\
\text { rides } 0.57\end{array}$ & [32] \\
\hline
\end{tabular}


[27] observed that without nitrogen-limiting conditions, the PHB content in dry cells decreased, whereas the EPS concentration increased, demonstrating that nutrientlimiting conditions promote only PHA accumulation.

\section{Bioenergy production from industrial and agricultural waste}

Anaerobic digestion and biogas production

Anaerobic digestion is a consolidated biological treatment, mainly used for reducing organic content in the sludge produced from municipal wastewater treatment plants, thus achieving its stabilization [95]. In the past few decades, the need to drastically reduce the use of landfills for the disposal of organic waste and producing energy from renewable resources has promoted the use of anaerobic digestion for treating a wide range of organic solids, e.g., organic waste and energy crops [96, 97]. To calculate bioenergy production potential based on anaerobic digestion for biomethane, official data for food waste generation and management were collected by Dung et al. [98] from 21 countries, evaluating a methane potential equal to $379.769 \mathrm{kWh}_{\text {year }}{ }^{-1}$.

Treatment systems based on the anaerobic digestion process are flexible because they can have different configurations according to the number of stages (one or two stages); can operate at different temperatures, mostly at $35{ }^{\circ} \mathrm{C}$ (mesophilic) or $55{ }^{\circ} \mathrm{C}$ (thermophilic); can be fed in batch, semi-batch, or continuous; can take place in completely stirred or plug flow reactors; and can work with a content of solids lower than $10 \%$ in mass (wet system) or higher than 20\% (dry system), preceded by several innovative pretreatments to increase waste solubilization [99].

Treating organic waste through anaerobic digestion results in economic and environmental advantages [97-100]; after treatment, the waste material is reduced in quantity, and it is more stable and less harmful for the environment because it is a source of a renewable energy, e.g., biogas, that does not alter the balance of $\mathrm{CO}_{2}$ in the atmosphere and therefore does not contribute to global warming [101]. Additionally, biogas refined to biomethane is also used to feed gas networks [102] as a surrogate to natural gas, and finally, the by-product of anaerobic digestion, named digestate, can be reused in agriculture as fertilizer $[103,104]$ thanks to its relevant content of nutrients. The performance and results of anaerobic digestion are strictly dependent on the environmental conditions [105-108], such as temperature, $\mathrm{pH}$, nutrients content, presence of inhibitors [107], substrate composition and particle size, micronutrient availability, and the microbial strains used as the inoculum. Anaerobic digestion is driven by a complex microbiome containing both bacteria and Archaea. Each trophic group in the microbiome contains different microorganisms involved in different metabolic tasks [109]. A strong syntrophic relationship exists between different consortia of microorganisms, since biochemical reactions in series are carried out (Fig. 2). Bacteria are crucial in the hydrolyzation and acidogenic step of the anaerobic digestion process.

Novaes [110] reported that the anaerobic species belonging to the families Streptococcaceae and Enterobacteriaceae as well as the genera Bacteroides, Clostridium, Butyrivibrio, Eubacterium, Bifidobacterium, and Lactobacillus are most commonly involved in the anaerobic digestion process. Furthermore, during the process, bacteria, such as Clostridia, fermented the hydrolyzed products of proteins to VFAs, $\mathrm{CO}_{2}$, and hydrogen $\left(\mathrm{H}_{2}\right)$.

In addition, Archaea are important in the methanogenic phase of anaerobic digestion. Methanogenic Archaea are strictly anaerobic and are able to transform fermentation products into $\mathrm{CH}_{4}$ [111]. Some of these bacteria synthesize $\mathrm{CH}_{4}$ using acetic acid, including the Methanosaeta, Methanosarcina, and Methanothrix genera. These are acetoclastic or acetotrophic methanogens. Additionally, other groups of methanogens synthesize $\mathrm{CH}_{4}$ by utilization of $\mathrm{H}_{2}$ and $\mathrm{CO}_{2}$ or methyl compounds, such as Methanobacterium, Methanococcus, Methanospirillum, or Methanomassiliicoccus [111].

These bacteria are potentially able to use all types of biomass suitable for producing biogas: sewage sludge from aerobic wastewater treatment, animal manure, harvest residues, organic waste from agriculture and food processing factories, dairy waste, organic fraction of municipal solid waste (OFMSW), fruit and vegetable waste, and energy crops, which are substrates commonly used for feeding anaerobic digesters [112].

The amount of biogas obtainable from a specific substrate depends on the operating conditions and its content of carbohydrates, proteins, and lipids. Lipids require a longer time than carbohydrates and proteins to be converted into biogas but have a more efficient conversion rate in terms of biogas produced per gram of substrate thanks to a high number of $\mathrm{C}$ and $\mathrm{H}$ atoms in their molecules [113]. Lipids are commonly present in food waste and in several wastewater types from factories, such as those that process meat, produce dairy, or refine fat [114]. Lipids can often be the cause of inconveniences, such as the inhibition of methanogenic microorganisms or their flotation and subsequent washout [115].

Organic waste from agriculture, food waste, and OFMSW is mainly composed of carbohydrates. Such wastes are easily degraded; if their feeding is not accurately controlled, volatile fatty acids (VFAs) produced by the acidification step of the anaerobic digestion tend to accumulate, causing a sharp drop in the $\mathrm{pH}$ value, which inhibits the activity of methanogenic Archaea [116] and leads to underperformance of the process. 


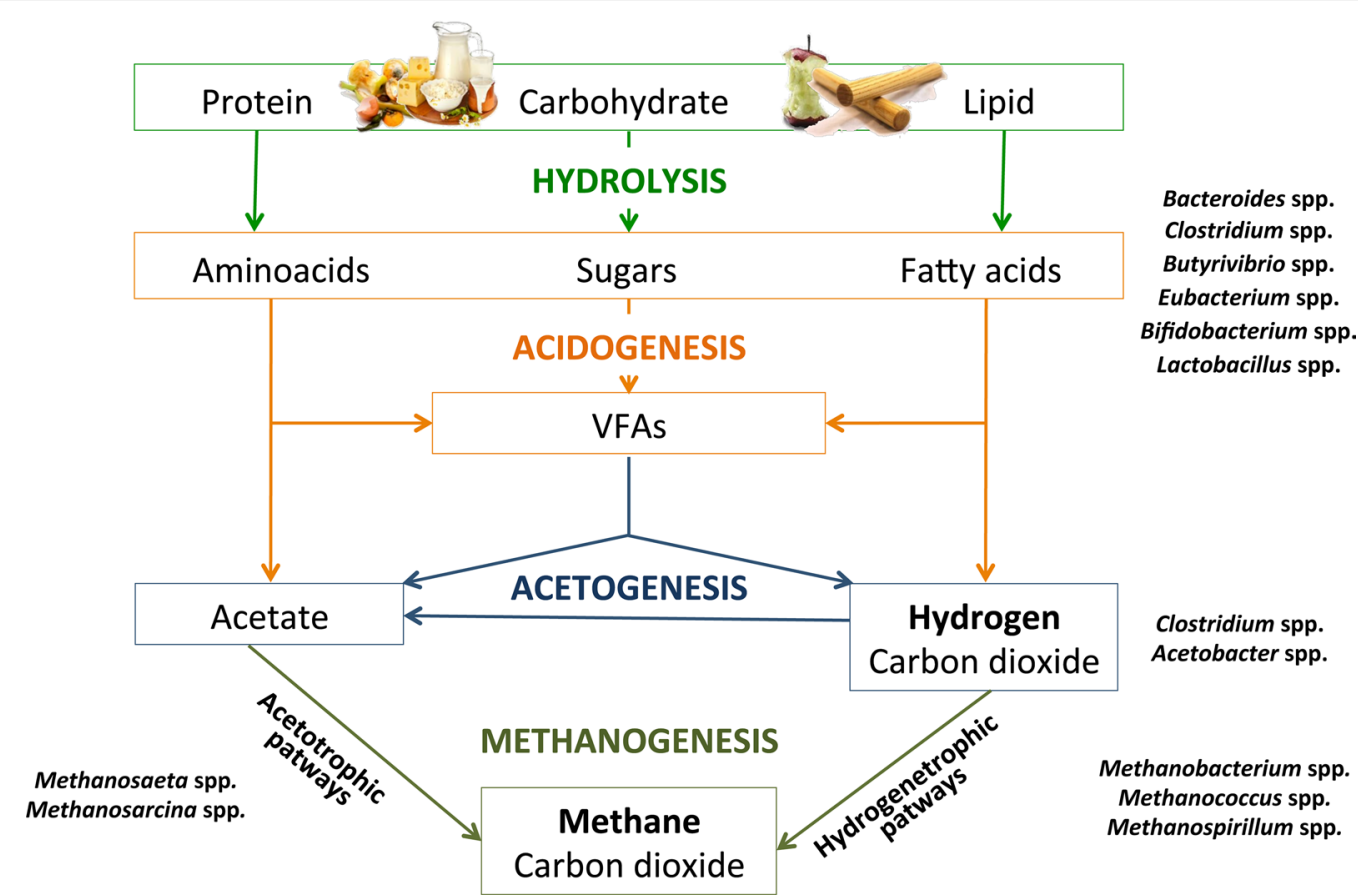

Fig. 2 Phases of biological production of methane with the occurrence of VFAs, acetate, hydrogen, and carbon dioxide. Anaerobic bacteria involved are positioned according to their probable role in the process

Wastes rich in proteins are commonly produced by meat and fish processing factories, slaughterhouses, and farms (animal slurry and manure). These wastes are characterized by a low $C / N$ ratio [117-119] that can hamper and even inhibit the activities of microorganisms [120]. Furthermore, proteins undergoing anaerobic digestion are converted into ammonia as an end product, which is rather toxic to microorganisms [121] and should be considered when looking for cost-effective ammonia removal techniques [122].

Wastes rich in cellulose (CWs) are produced by paper and cardboard as well as textile factories. CWs are also found, in large amounts, in unsorted municipal solid wastes (MSWs) and therefore are not useful for recycling. The $C / N$ ratio in CWs is usually high, ranging from $173 / 1$ up to values higher than 1000/1 [123], while the optimum $C / N$ ratio ranges from $20 / 1$ to $30 / 1$ [124].

Microalgae can be an alternative substrate for renewable energy recovery. The co-digestion of microalgae with different types of wastes, such as pig/dairy manure [125], lipid waste (fat, oil, and grease) [126], waste activated sludge [127], and corn straw [128], has been extensively evaluated for biomethane production. Zhen et al. [129] examined the technical potential of methane production from microalgae through co-digesting with food waste. The results showed that supplementing food waste significantly improved microalgae digestion performance compared to the digestion of a single food waste, with the highest methane yield of $639.8 \pm 1.3 \mathrm{ml} \mathrm{g}^{-1} \mathrm{VS}_{\text {added }}$.

In fact, an estimation of the amount of methane that can be produced from a specific substrate is commonly obtained through a specific test called the biomethane potential test (BMP). The BMP can be used as an index of the anaerobic biodegradation potential, as it is the experimental value of the ultimate specific biomethane production for the indefinite degradation time [130]. However, in practice, BMP is estimated at a well-defined degradation time that can be a specific day, e.g., the 30th [131, 132] or 50th [133] of incubation or the day when biomethane production is approximately zero [134] or less than $5 \mathrm{mld}^{-1}$ [131]. BMP can be expressed specifically as a volume of methane per amount of waste $\left(\mathrm{dm}^{3} \mathrm{CH}_{4}\right.$ $\mathrm{kg}^{-1}$ waste), volume of waste $\left(\mathrm{dm}^{3} \mathrm{CH}_{4} \mathrm{dm}^{-3}\right.$ waste), per mass volatile solids added $\left(\mathrm{dm}^{3} \mathrm{CH}_{4} \mathrm{~kg}^{-1} \mathrm{VS}\right)$, or COD (chemical oxygen demand) added ( $\left.\mathrm{dm}^{3} \mathrm{CH}_{4} \mathrm{~kg}^{-1} \mathrm{COD}\right)$. The volume is usually expressed at standard conditions in terms of pressure $(1 \mathrm{~atm})$ and temperature $\left(0{ }^{\circ} \mathrm{C}\right)$. Other units for expressing methane potential are also used [135].

For the same substrate, the BMP results can be variable because it is affected by the operating conditions in terms of temperature, mixing intensity, $\mathrm{pH}$ adjustment, substrate/inoculum (S/I) ratio, substrate particle size, liquid/volume ratio, nutrient content, inoculum, and if the 
substrate has been previously pretreated (e.g., mechanically, thermally, chemically) or mixed with one or more other substrates to perform a co-digestion process [136]. In Table 8, the methane yields from different substrates are reported (adapted from Raposo et al. [112]).

\section{Biohydrogen production}

Hydrogen is considered an ideal source of energy because it represents a clean combustible and is also easily convertible to electricity [137]. Biological hydrogen production is related to biogas production for two main reasons: a similar production process, and the same substrates are suitable. These two gaseous products are derived from the same biological process that switches on hydrogen production when hydrogen-using microorganisms are inhibited, such as homoacetogens and methanogens; inhibition is commonly achieved through heat treatment

Table 8 Methane yields of solid organic substrates. Adapted from Raposo et al. [85]

\begin{tabular}{|c|c|c|}
\hline Solid organic substrate & $\begin{array}{l}\text { Methane yield } \\
{\left[\mathrm{ml} \mathrm{CH}_{4} \mathrm{~g}^{-1} \mathrm{VS}_{\text {added }}\right]}\end{array}$ & References \\
\hline Apple fresh wastes & 317 & [179] \\
\hline Banana peeling & 289 & [179] \\
\hline Cabbage leaves $2 \mathrm{~mm}$ size & 309 & [180] \\
\hline Carrot peeling & 388 & [179] \\
\hline Cauliflower leaves & $341-352$ & [181] \\
\hline Cellulose & $356-375$ & [132] \\
\hline Cocksfoot & 325 & [182] \\
\hline Food wastes & $245-510$ & [183] \\
\hline Fruit and vegetable wastes & 470 & [184] \\
\hline Glucose & 335 & [185] \\
\hline Kitchen waste & 432 & [115] \\
\hline Leather fleshing & 490 & [186] \\
\hline Lettuce residues & 294 & [179] \\
\hline Maize residues & 317 & [187] \\
\hline Mandarin peels $2 \mathrm{~mm}$ size & 486 & [180] \\
\hline OFMSW & 353 & [188] \\
\hline Orange peeling & 297 & [179] \\
\hline Paper and cardboard & $109-128$ & [189] \\
\hline Pineapple peel & 400 & [190] \\
\hline Potato waste & 320 referred to gVS removed & [191] \\
\hline Rape oil seed & $800-900$ & [133] \\
\hline Rice straw & $347-367$ & [192] \\
\hline Starch & 348 & [133] \\
\hline Sugar beet & 340 & [193] \\
\hline Sunflower & $428-454$ & [194] \\
\hline Textiles & 228 & [195] \\
\hline Tomato skins and seeds & 218 & [187] \\
\hline Wheat straw & 267 & [196] \\
\hline Algal biomass & 640 & [129] \\
\hline
\end{tabular}

of the inoculum to remove all microorganisms, except for spore-forming fermenting bacteria (i.e., species belonging to the families Clostridiaceae, Streptococcaceae, Sporolactobacillaceae, Lachnospiraceae, and Thermoanaerobacteriacea) [138]. The most common bacteria used in dark fermentation to produce hydrogen are Clostridium [139] and Thermoanaerobacterium [140, 141]. Moreover, several studies have reported successful hydrogen production by mixed cultures in batch or bioreactors $[142,143]$. The advantages of using mixed cultures for biohydrogen production are several and are as follows: no need for sterilization, a high adaptive capacity owing to the microbial diversity, the capacity to use a mixture of substrates, and the possibility of obtaining a stable and continuous process [141].

Furthermore, the same organic substrates, such as solid waste, can be used to produce biogas and biohydrogen, thus converting residues into a source of bio-energies [138]. Many processes for hydrogen production have been extensively investigated; among them, hydrogen production by photosynthetic bacteria, algae, and fermentative bacteria is the most interesting because it is environmentally sustainable.

In autotrophic conversions, biohydrogen can be produced by photosynthetic microorganisms, i.e., microalgae and photosynthetic bacteria that convert solar energy to hydrogen [144]. Photosynthetic bacteria (e.g., purple non-sulfur bacteria) utilize the end products of dark fermentation, converting them into $\mathrm{H}_{2}$ via photofermentation with simultaneous VFA reduction [145-150]. The major limitation of photofermentation systems is its poor $\mathrm{H}_{2}$ production rate due primarily to the slow growth of photosynthetic bacteria and the low light conversion efficiency of photobioreactors [149]. A photobioreactor (PBR) was developed by Chen et al. [149] to enhance phototrophic $\mathrm{H}_{2}$ production by Rhodopseudomonas palustris WP3-5 using acetate as the sole carbon source. The photobioreactor was illuminated by combinative light sources, reaching a maximum $\mathrm{H}_{2}$ yield of $62.3 \%$.

Under heterotrophic conditions, two types of fermentation occur: photofermentation carried out by photosynthetic bacteria and dark fermentation [151] carried out by anaerobic bacteria that convert carbohydrates into biohydrogen [144]. Different rumen bacteria, such as Clostridia, methylotrophs, methanogenic archae, or facultative anaerobic bacteria (E. coli, Enterobacter spp., Citrobacter spp.), and aerobic bacteria (Alcaligenes spp., Bacillus spp.) have been studied to perform dark fermentation. In particular, Clostridium butyricum and Clostridium articum produce butyric acid and propionate as major products, respectively, and both products are of interest for hydrogen production [152]. Indeed, photofermentation takes place under anaerobic conditions 
involving purple non-sulfur photosynthetic bacteria using light as an energy source for synthesizing hydrogen [153]. The ability of purple non-sulfur bacteria to convert organic acids to biohydrogen is coupled with their ability to synthesize PHB under anaerobic conditions.

In fact, Luongo et al. [154] investigated hydrogen and poly-b-hydroxybutyrate (PHB) production during photofermentative treatment of the effluent from a dark fermentation reactor fed with the organic fraction of municipal solid waste. They compared the hydrogen and PHB production of an adapted culture of Rhodobacter sphaeroides AV1b and a mixed consortium of purple non-sulfur bacteria. The mixed cultures resulted in 1.5-fold more $\mathrm{H}_{2}$ produced than the pure culture (559 and $364 \mathrm{~N} \mathrm{ml} \mathrm{H}_{2} \mathrm{l}^{-1}$, respectively). On the contrary, $R$. sphaeroides cultures showed higher PHB productivity (155 mg PHB g COD ${ }^{-1}$ ) than the mixed cultures (55 mg PHB g $\mathrm{COD}^{-1}$ ).

As for methane production through anaerobic digestion, biohydrogen can be produced by different bacterial strains using several organic substrates. For example, Cappelletti et al. [155] focused their study on $\mathrm{H}_{2}$ production from molasses and cheese whey with the aim of valorizing food industry wastes by their recycling; mesophilic, thermophilic, and hyperthermophilic bacteria were tested to produce $\mathrm{H}_{2}$. Among them, Thermotoga strains showed the most promising results; in particular, T. neapolitana was the best performing strain (Table 9). This result was confirmed by studies conducted on $T$. neapolitana using other organic substrates, such as rice straw [156], beet pulp pellet, corn starch, and rice flour [157]. Such substrates are particularly suitable for producing $\mathrm{H}_{2}$ thanks to their easy biodegradability and are also convenient because they are present in different carbohydrate-rich wastewaters and agricultural residues [158]. Other substrates commonly used for biohydrogen production are protein- and fat-rich wastes. A C. butyricum strain was studied by Chen et al. [159] for its ability to produce $\mathrm{H}_{2}$ from a sucrose-based medium. In particular, C. butyricum CGS5 can efficiently produce hydrogen (2.78 $\mathrm{mol} \mathrm{H}_{2} \mathrm{~mol}^{-1}$ sucrose) on an iron-containing medium [159]. The same microbial strain (C. butyricum CGS5) was isolated from soil with nine cellulolytic bacterial strains belonging to Cellulomonas sp. and Cellulosimicrobium cellulans by Lo et al. [160]. Among these strains, only C. butyricum CGS5 exhibited efficient $\mathrm{H}_{2}$ production from rice husk hydrolysates, with a $\mathrm{H}_{2}$ yield of $17.24 \mathrm{mmol} \mathrm{H}_{2}$ g cellulose ${ }^{-1}$.

Ferchichi et al. [161] investigated hydrogen production from cheese whey by Clostridium saccharoperbutylacetonicum, studying the influence of the initial $\mathrm{pH}$; they found that slightly acidic initial conditions favored a higher $\mathrm{H}_{2}$ yield than alkaline conditions. The highest hydrogen yield ( $2.7 \mathrm{~mol} \mathrm{H}_{2} \mathrm{~mol}^{-1}$ substrate) was actually obtained at pH 6. Bisaillon et al. [162] examined hydrogen production by different strains of Escherichia coli under different feeding regimes to detect the main limiting factors: strains that showed the highest hydrogen yield ( $2 \mathrm{~mol} \mathrm{H}_{2} \mathrm{~mol}^{-1}$ substrate) when cultured at limiting concentrations of either ammonia or glucose $(1 \mathrm{mM}$ $\mathrm{NH}_{4} \mathrm{Cl} ; 0.04 \%$ of glucose). Mesophilic bacterium HN001 was tested by Yasuda and Tanisho [163] as a $\mathrm{H}_{2}$ producer from starch. In the same work, the authors focused their studies on the influence of temperature, $\mathrm{pH}$, and substrate concentration; the optimal temperature was found to be approximately $37^{\circ} \mathrm{C}$, with a hydrogen yield of $2 \mathrm{~mol} \mathrm{H}_{2} \mathrm{~mol}^{-1}$ substrate. Liu et al. [164] investigated $\mathrm{H}_{2}$ production by mixed cultures in batch experiments using

Table 9 Hydrogen yields of different substrates. Adapted from Li and Fang [141], Davila-Vazquez et al. [158]

\begin{tabular}{|c|c|c|c|}
\hline Substrate & Strain & Hydrogen yield & References \\
\hline Sucrose & Clostridium butyricum CGS5 & $2.78\left[\mathrm{~mol} \mathrm{H}_{2} \mathrm{~mol}^{-1}\right.$ substrate $]$ & [159] \\
\hline Glucose & Escherichia coli strains & $2\left[\mathrm{~mol} \mathrm{H}_{2} \mathrm{~mol}^{-1}\right.$ substrate] & {$[162]$} \\
\hline Glucose & Thermotoga neapolitana & $1.6\left[\mathrm{~mol} \mathrm{H} \mathrm{mol}^{-1}\right.$ substrate] & {$[155]$} \\
\hline Molasses & Thermotoga neapolitana & $2.6\left[\mathrm{~mol} \mathrm{H} \mathrm{mol}^{-1}\right.$ substrate] & {$[155]$} \\
\hline Rice straw & Thermotoga neapolitana & $2.7\left[\mathrm{~mol} \mathrm{H}_{2} \mathrm{~mol}^{-1}\right.$ substrate $]$ & {$[156]$} \\
\hline Cheese whey & Thermotoga neapolitana & $2.4\left[\mathrm{~mol} \mathrm{H}_{2} \mathrm{~mol}^{-1}\right.$ substrate $]$ & {$[155]$} \\
\hline Cheese whey & Clostridium saccharoperbutylacetonicum ATCC 27021 & $2.7\left[\mathrm{~mol} \mathrm{H}_{2} \mathrm{~mol}^{-1}\right.$ substrate $]$ & {$[161]$} \\
\hline Starch & Mesophilic bacterium HN001 & $2\left[\mathrm{~mol} \mathrm{H}_{2} \mathrm{~mol}^{-1}\right.$ substrate] & {$[163]$} \\
\hline Starch & Mixed culture from compost & $133\left[\mathrm{ml} \mathrm{H}_{2} \mathrm{~g}^{-1}\right.$ hexose $]$ & {$[166]$} \\
\hline Cellulose & Mixed culture from sludge & $92\left[\mathrm{ml} \mathrm{H}_{2} \mathrm{~g}^{-1}\right.$ hexose $]$ & {$[164]$} \\
\hline Mixed waste & Mixed culture from anaerobic digestion sludge & $201\left[\mathrm{ml} \mathrm{H}_{2} \mathrm{~g}^{-1}\right.$ hexose $]$ & {$[168]$} \\
\hline Food waste & Mixed culture from anaerobic digestion sludge & $210\left[\mathrm{ml} \mathrm{H}_{2} \mathrm{~g}^{-1}\right.$ hexose $]$ & {$[167]$} \\
\hline Acetate & Rhodopseudomonas palustris WP3-5 in Photobioreactor & $62.3\left[\mathrm{~mol} \mathrm{H}_{2} \mathrm{~mol}^{-1}\right.$ substrate $]$ & {$[120]$} \\
\hline Rice husk & Clostridium butyricum CGS5 & $17.24\left[\mathrm{mmol} \mathrm{H} 2 \mathrm{~g}^{-1}\right.$ cellulose] & {$[160]$} \\
\hline
\end{tabular}


cellulose as a substrate; at the optimal $\mathrm{pH}$ of 6.5 , the maximum hydrogen yield was $92 \mathrm{ml} \mathrm{H}_{2} \mathrm{~g}^{-1}$ hexose, and an analysis of $16 \mathrm{~S}$ rDNA sequences showed that the cellulose-degrading mixed culture was composed of microbes closely affiliated with genus Thermoanaerobacterium. Carbohydrate-rich holocellulose of lignocellulosic organic matter can be made available to the $\mathrm{H}_{2}$ conversion by pretreatment. Examples of lignocellulosic biomass pretreatment methods for hydrogen fermentation were reported by Kumar et al. [165]. They also reported the maximum hydrogen yield associated with pretreatment methods, ranging from 44.9 to $141.29 \mathrm{ml} \mathrm{H}_{2} \mathrm{~g}^{-1}$.

The influence of $\mathrm{pH}$ was also evaluated by Khanal et al. [166], who used a mixed microbial culture and starch as a substrate. At the optimal $\mathrm{pH}$ of 4.5 , the maximum hydrogen yield was $133 \mathrm{ml} \mathrm{H}_{2} \mathrm{~g}^{-1}$ hexose. At the same $\mathrm{pH}$ value, Fang et al. [167] reached a maximum hydrogen yield of $210 \mathrm{ml} \mathrm{H}_{2} \mathrm{~g}^{-1}$ hexose using food waste as a substrate. Instead, Valdez-Vazquez et al. [168] studied the influence of temperature using a mixed culture as the inoculum and mixed waste as a substrate. At $37{ }^{\circ} \mathrm{C}$, the maximum hydrogen yield was $210 \mathrm{ml} \mathrm{H}_{2} \mathrm{~g}^{-1}$ hexose.

All biotechnological hydrogen production processes have particular limits, since a considerable part of the used substrate is converted into various soluble metabolic products rather than $\mathrm{H}_{2}$. Thus, the major side product of dark fermentation is a multi-compound mixture of VFAs and other constituents, such as alcohols [169]. Therefore, the volatile fatty acid-rich fermentation effluent is a perfect substrate for biologically synthesizing polyesters, e.g., polyhydroxyalkanoate [170, 171], which could have an industrial market [172].

\section{Integrated systems for bioenergy production from industrial and agricultural wastes Simultaneous production of PHAs and bioenergy from organic wastes}

Degradation of biowaste to methane $\left(\mathrm{CH}_{4}\right)$ and carbon dioxide is a multiple step process with the possibility of producing $\mathrm{H}_{2}$ and bioplastics (from volatile fatty acids) as intermediates [17]. Based on this process, anaerobic digestion can be performed with a two-stage system, where biomass is degraded in the first stage and hydrolysis-acidification occurs. The organic acids produced are processed under aerobic conditions to produce biopolymers and, as an alternative, under anaerobic conditions to produce biogas.

A PHA production system, in its most comprehensive configuration, is composed of four main stages (Fig. 3), as follows:

1. Feedstock production,

2. Biomass selection,
3. PHA production, and

4. PHA extraction.

Simplified configurations can be obtained using synthetic substrates (stage 1 is removed from the cycle), using pure culture (stage 2 is removed from the cycle), or using both synthetic substrates and pure culture (stages 1 and 2 are removed from the cycle).

The aims of each stage are listed below:

1. To produce organic acids from complex organic solids (e.g., wastes rich in carbohydrates),

2. To select the microbial strains from the mixed culture that show the highest capacity for PHA accumulation under specific dynamic feeding conditions [173],

3. To produce PHAs using the selected culture, and

4. To recover PHAs from microorganisms.

A dark fermentation process can be successfully used to perform the first stage. This process evolves according to the same sequence of biochemical reactions in the anaerobic digestion process, with the exception of the last stage that is repressed using different strategies (e.g., setting a short hydraulic retention time-HRT, keeping the $\mathrm{pH}$ low at 5.5, adding chemical compounds toxic to methanogens, and performing thermal shocks).

The dark fermentation process can be optimized to produce VFAs and consequently $\mathrm{H}_{2}$ that is a by-product of the biological process and VFAs, varying (i) the operational conditions (i.e., $\mathrm{pH}$, temperature, HRT, solid retention time-SRT, organic loading rate-OLR); (ii) the configuration of the dark fermentation reactor and feeding system; and (ii) the type of organic waste used to feed the reactor (Fig. 4). The effects of these parameters on VFA production are listed in Table 10 [174].

Various microbes, such as A. eutrophus, B.s megaterium, P. oleovorans, A. beijerincki, Rhizobium, and Nocardia, utilize acetic acid, formic acid, and propionic acid as a substrate for PHA production [70]. A. eutrophus and A. beijerinckii were studied by Kalia et al. [70] and were shown to be capable of accumulating PHAs up to $70 \%$ of CDW, under nitrogen and phosphoruslimiting conditions, whereas Pseudomonas spp. and Rhizobium spp. accumulated PHAs at approximately $60 \%$ of CDW.

Many other bacterial strains have also been reported to produce PHAs under adverse conditions with different PHA yields. Among them, many purple non-sulfur bacteria, such as $R$. sphaeroides, Rhodospirillum rubrum, Rhodopseudomonas palustris, Rhodopseudomonas palustris, and Bacillus spp., have been reported to produce $\mathrm{H}_{2}$ and PHA under nutrient-limiting conditions [175]. 


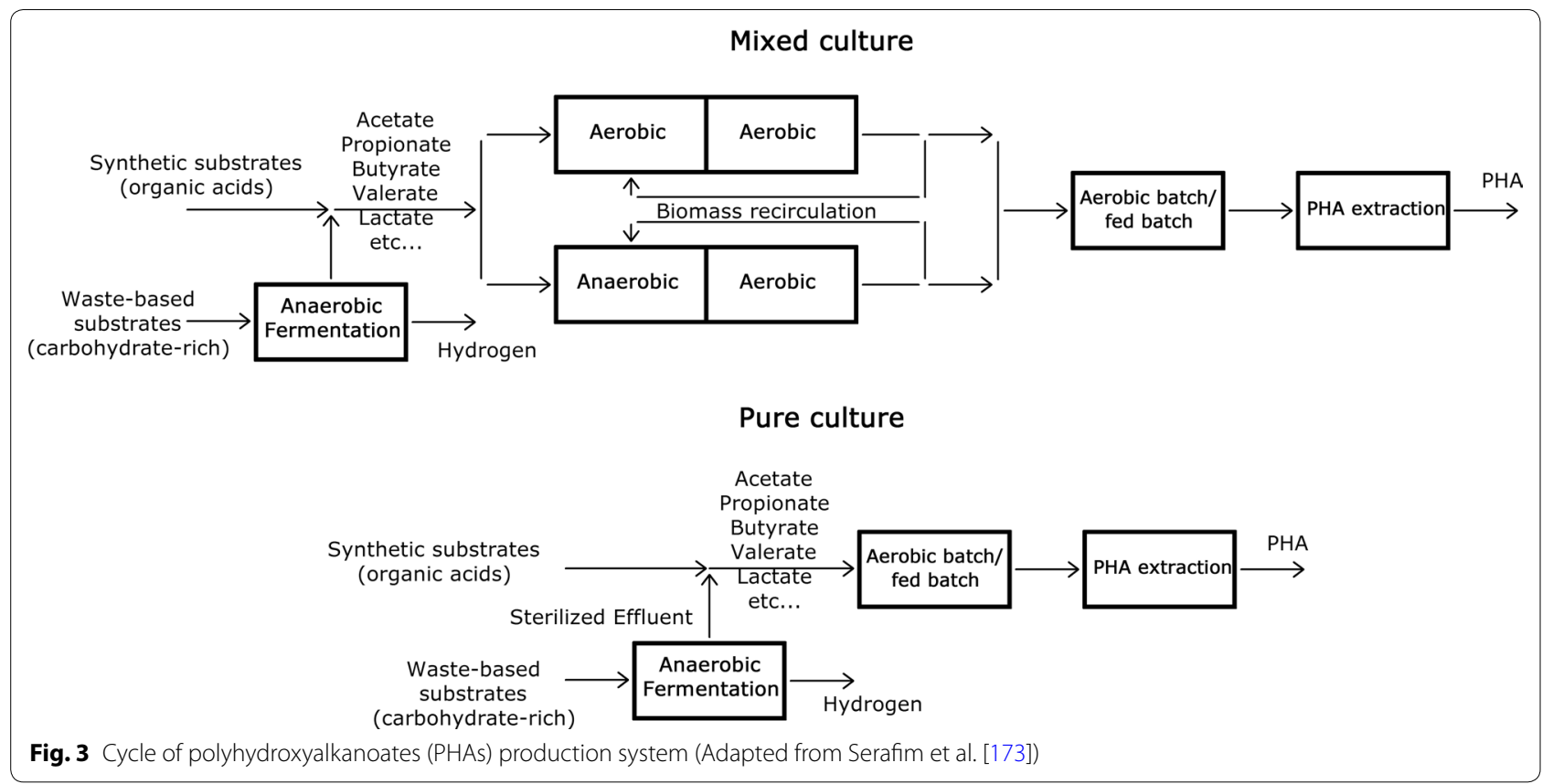

Patel et al. [17] investigated the metabolic activities of Bacillus strains to transform glucose into $\mathrm{H}_{2}$ and $\mathrm{PHB}$ in two stages. Operating in batch mode, Bacillus thuringiensis EGU45 and B. cereus EGU44 reached 1.67$1.92 \mathrm{~mol} \mathrm{H}_{2} \mathrm{~mol}^{-1}$ glucose, respectively, during the first 3 days. In the next 2 days, Bacillus thuringiensis EGU45 was supplemented with residual medium containing glucose, volatile fatty acids, and residual nutrients (nutrient stress condition) and produced a PHB yield of $11.3 \%$ of CDW.

Rhodopseudomonas palustris WP3-5 was studied by Wu et al. [176] to evaluate possible competition between PHB synthesis and $\mathrm{H}_{2}$ production, testing cultures on six different substrates, such as acetate, propionate, malate, lactate, glucose, and lactose. The results highlighted that strain WP3-5 could utilize acetate, propionate, malate, and lactate to produce $\mathrm{H}_{2}$, whereas it was also able to synthesize PHB only on acetate and propionate. PHB synthesis decreased $\mathrm{H}_{2}$; however, under $\mathrm{pH}$-stress conditions, such a decrease was not observed.

Rhodopseudomonas palustris was also studied by Vincenzini et al. [177] to investigate the potential of purple non-sulfur bacteria in the photoproduction of both hydrogen and PHB-containing biomass under limiting amounts of nitrogen. The data demonstrated that under nitrogen-limiting growth conditions, $R$. palustris synthesized $40 \mathrm{mg} \mathrm{l}^{-1}$ day $^{-1}$ of PHB and produced $200 \mathrm{ml} \mathrm{l}^{-1}$ day of $\mathrm{H}_{2}$ when the experiments were supplemented with $60 \mathrm{mg} \mathrm{l}^{-1}$ day $^{-1}$ of nitrogen.

$\mathrm{Yu}$ [26] performed a two-step integrated system consisting of microbial acidogenesis and acid polymerization from starchy wastewater. In his work, the starchy organic waste was first digested in a thermophilic upflow anaerobic sludge blanket reactor to form acetic $(60-80 \%)$, propionic $(10-30 \%)$, and butyric (5-40\%) acids. The acids in the effluent solution after microfiltration were polymerized into PHAs by $A$. eutrophus in a second reactor. PHA production from the acid effluent was compared with the production from pure acids in $48 \mathrm{~h}$, and the results were very similar. In batch mode, $1.2 \mathrm{~g} \mathrm{l}^{-1}$ of PHAs was accumulated from acid effluent. Instead, 1.0 and $1.3 \mathrm{~g} \mathrm{l}^{-1}$ of PHAs were obtained from a mixture of butyric acid and propionic acid in batch and fed-batch mode, respectively.

Albuquerquea et al. [178] designed another integrated system to valorize the use of wastewater for PHA production. They employed a 2-stage continuous stirred tank reactor (CSTR) system to effectively select PHA-storing organisms using fermented molasses as feedstock. The acidogenic fermentation (step 1) was carried out in a CSTR operated under anaerobic conditions. The reactor effluent was clarified by microfiltration and used as a feedstock for culture selection (step 2) and PHA batch accumulation (step 3). The culture reached a maximum PHA content of $61 \%$.

The best integrated system developed was based on two-step processes consisting of acidogenic fermentation (operating under anaerobic condition) aimed to produce acid effluent that, after microfiltration, is used in the subsequent aerobic microbial process aimed at PHA polymerization. However, the first step (acidogenic 


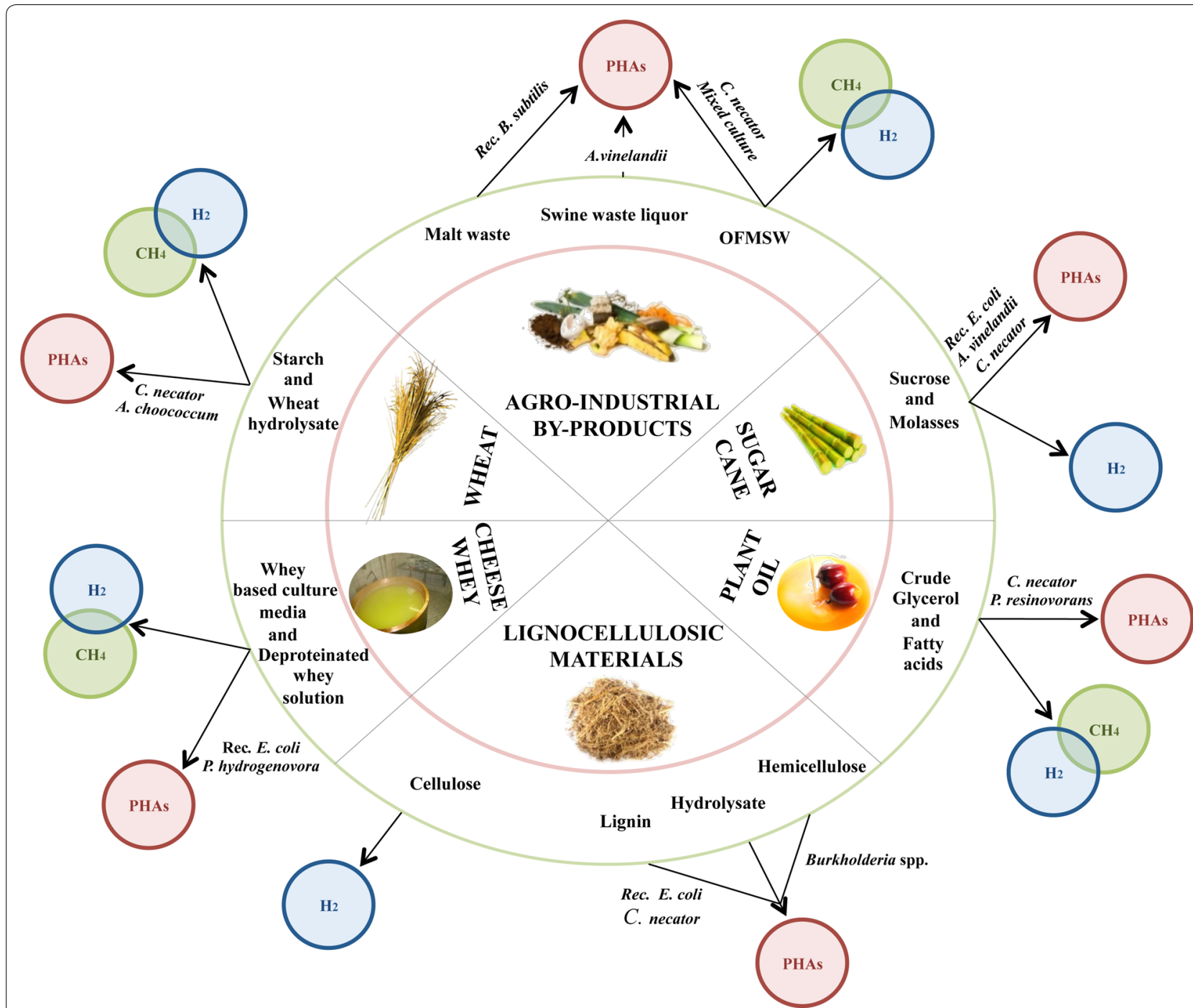

Fig. 4 Sustainable PHAs and bioenergy production from organic wastes and by-products converted by different bacterial species: an overview of the principal process considered in this review

fermentation) is also useful for hydrogen production and could be designed as a dark fermentation process.

\section{Conclusions}

Biological processes can be successfully used in innovative and eco-sustainable technology to convert organic waste into bioenergy and biochemicals, separately or simultaneously. Bioprocesses can provide bioenergy or valuable chemicals and, at the same time, perform pollution control, according to technical feasibility, simplicity, economics, and societal needs. Bio-based plastics can completely replace the conventional ones derived from fossil fuels if the production costs can be reduced, and the use of high-performing bacteria fed with organic wastes and by-products as substrates significantly contribute to achieving this objective.

In this context, different organic substrates and byproducts can be used to produce bioenergy (hydrogen and methane) and biopolymers (PHAs). Otherwise, the review highlights the possibility of integrating the two production processes to design a unique system for both energy and biopolymer production. The integrated system is a flexible process that aims (i) to produce organic acids from complex organic solid wastes rich in carbohydrates; (ii) to use selected microbial strains or mixed cultures that show the highest capacity for PHA accumulation under specific dynamic feeding conditions; and (iii) to produce bioenergy or accumulate PHAs by microorganisms from acidogenic effluents. 
Table 10 Waste, reactor configuration, and operation for the production of VFAs Adapted from Lee et al. [174]

\begin{tabular}{|c|c|c|c|c|}
\hline Type of waste & $\begin{array}{l}\text { Organic content } \\
\left(\mathrm{mg} \mathrm{COD}^{-1}\right)\end{array}$ & Reactor type and operating conditions & VFA production & References \\
\hline \multirow[t]{2}{*}{ Waste activated sludge } & 18.657 & Batch, $55^{\circ} \mathrm{C}, \mathrm{pH}=8, \mathrm{HRT}=9$ days & $368 \mathrm{mg} \mathrm{COD} \mathrm{gVSS}^{-1}$ & [197] \\
\hline & 14.878 & Batch, $21^{\circ} \mathrm{C}, \mathrm{HRT}=6$ days & $339 \mathrm{mg} \mathrm{COD} \mathrm{l^{-1 }}$ & [198] \\
\hline \multirow[t]{2}{*}{ Primary sludge } & 22.838 & Batch, $21^{\circ} \mathrm{C}, \mathrm{HRT}=6$ days & $85 \mathrm{mg} \mathrm{COD} \mathrm{gVSS}^{-1}$ & [199] \\
\hline & 20.631 & Batch, $21^{\circ} \mathrm{C}, \mathrm{pH}=10$, room temp, $\mathrm{HRT}=5$ days & $60 \mathrm{mg} \mathrm{COD} \mathrm{gVsS}^{-1} \mathrm{day}^{-1}$ & {$[200]$} \\
\hline \multirow[t]{2}{*}{ Food waste } & 91.900 & Batch, $37^{\circ} \mathrm{C}, \mathrm{pH}=5.5$ & $8950 \mathrm{mg} \mathrm{COD} \mathrm{I}^{-1}$ & [201] \\
\hline & 146.1 & Batch, $35^{\circ} \mathrm{C}, \mathrm{HRT}=5$ days & $5610 \mathrm{mg} \mathrm{COD} \mathrm{I}^{-1}$ & [202] \\
\hline Kitchen waste & 166.18 & Batch, $35^{\circ} \mathrm{C}, \mathrm{pH}=7, \mathrm{HRT}=4$ days & $36 \mathrm{mg} \mathrm{l}^{-1}$ & [203] \\
\hline \multirow[t]{2}{*}{ OFMSW } & 347.0 & Batch, $14-22^{\circ} \mathrm{C}, \mathrm{pH}=4-5, \mathrm{HRT}=4-4.5$ days & $40 \mathrm{mg} \mathrm{g}^{-1} \mathrm{VS}$ & [204] \\
\hline & 196.7 & $\begin{array}{l}\text { Plug flow, } 37^{\circ} \mathrm{C}, \mathrm{pH}=5.7-6.1, \mathrm{HRT}=\mathrm{SRT}=6 \text { days, } \\
\text { OLR }=38.5 \mathrm{gVS} \mathrm{I}^{-1} \text { day }^{-1}\end{array}$ & $23.110 \mathrm{mg} \mathrm{l}^{-1}$ & [15] \\
\hline Palm oil mill & 88.0 & Semi-continuous, $30^{\circ} \mathrm{C}, \mathrm{pH}=6.5, \mathrm{HRT}=4$ days & $15.300 \mathrm{mg} \mathrm{l}^{-1}$ & {$[205]$} \\
\hline Olive oil mill & 37.0 & $\begin{array}{l}\text { Packed bed biofilm, } 25^{\circ} \mathrm{C}, \mathrm{pH}=5.2-5.5, \mathrm{HRT}=14 \\
\text { days, OLR }=26 \mathrm{~g} \mathrm{COD} \mathrm{I}^{-1} \mathrm{day}^{-1}\end{array}$ & $10.700 \mathrm{mg} \mathrm{COD}^{-1}$ & [206] \\
\hline Cheese whey & 4590 & $\mathrm{CSTR}, 37^{\circ} \mathrm{C}, \mathrm{pH}=6, \mathrm{HRT}=2.1$ days & $0.84 \mathrm{gVFA}^{-C O D} \mathrm{~g}^{-1} \mathrm{sCOD}^{-1}$ & [207] \\
\hline
\end{tabular}

This integrated system represents new perspectives on the use of organic waste and by-products, valorizing organic substrates for the production of both bioenergy and PHAs.

\begin{abstract}
Abbreviations
OFMSW: organic fraction of municipal solid waste; PHAs: polyhydroxyalkanoates; EPS: exopolysaccharides; GHG: green house gas; SCL: short-chain length; MCL: medium-chain length; P(3HB): poly(3-hydroxybutyrate); PHB: polyhydroxybutyrate; $3 \mathrm{HV}$ : 3-hydroxyvalerate; 4HB: 4-hydroxybutyrate; P(3HB-3HV): poly(3-hydroxybutyrate-co-3-hydroxyvalerate); LCA: life cycle assessment; CDW: cell dry weight; C/N: carbon-to-nitrogen ratio; PHBV: poly(hydroxybutyrate-co-hydroxyvalerate); UASB: upflow anaerobic sludge blanket; AO: alginate oligosaccharides; VFAs: volatile fatty acids; CWs: cellulose wastes; BMP: biomethane potential test; COD: chemical oxygen demand; $\mathrm{S} / \mathrm{I}$ : substrate/inoculums ratio; HRT: hydraulic retention time; SRT: solid retention time; OLR: organic loading rate.
\end{abstract}

\section{Authors' contributions}

GP developed the whole manuscript preparing and integrating the different parts. WV contributed to write the microbiological aspects of the work and revised the manuscript. AP contributed to write the process system aspects of the work, prepared Table 8, and revised the manuscript. OP conceived the study, participated in its design, and revised the manuscript. All authors read and approved the final manuscript.

\section{Author details}

${ }^{1}$ Division of Microbiology, Department of Agricultural Sciences, University of Naples Federico II, Via Università 100, Portici, 80055 Naples, Italy. ${ }^{2}$ Telematic University Pegaso, Naples, Italy.

\section{Acknowledgements}

Not applicable.

\section{Competing interests}

The authors declare that they have no competing interests.

\section{Funding}

This study was supported by grant from the Ministero dell'Università e della Ricerca Scientifica Industrial Research Project "Development of green technologies for production of BIOchemicals and their use in preparation and industrial application of POLImeric materials from agricultural biomasses cultivated in a sustainable way in Campania region-BioPoliS"PON03PE_00107_1/1, funded in the frame of Operative National Programme Research and Competitiveness 2007-2013 D. D. Prot. n. 713/Ric. on 29.10.2010.

\section{Publisher's Note}

Springer Nature remains neutral with regard to jurisdictional claims in published maps and institutional affiliations.

Received: 31 January 2017 Accepted: 23 April 2017

Published online: 02 May 2017

\section{References}

1. Bauen A, Berndes $G$, Junginger M, Londo M, Vuille F, Ball R, Bole T, Chudziak C, Faaij A, Mozaffarian H. Bioenergy — a sustainable and reliable energy source. Rev Status Prospects. 2009. http://www.ieabioenergy. com/Libltem.aspx?id=6479.

2. Mezule WL, Dalecka B, Juhna T. Fermentable sugar production from lignocellulosic. Chem Eng Trans. 2015;43:619-24. doi:10.3303/ CET1543104.

3. Liguori R, Ventorino V, Pepe $O$, Faraco V. Bioreactors for lignocellulose conversion into fermentable sugars for production of high added value products. Appl Microbiol Biotechnol. 2016;100:597-611. doi:10.1007/ s00253-015-7125-9.

4. Ventorino V, Robertiello A, Viscardi S, Ambrosanio A, Faraco V, Pepe O. Bio-based chemical production from Arundo donax feedstock fermentation using Cosenzaea myxofaciens BPM1. BioResources. 2016;11:6566-81.

5. Ventorino V, Robertiello A, Cimini D, Argenzio O, Schiraldi C, Montella S, Faraco V, Ambrosanio A, Viscardi S, Pepe O. Bio-Based succinate production from Arundo donax hydrolysate with the new natural succinic acid-producing strain Basfia succiniciproducens BPP7. Bioenergy Res. 2017. doi:10.1007/s12155-017-9814-y.

6. Saratale GD, Jung MY, Oh MK. Reutilization of green liquor chemicals for pretreatment of whole rice waste biomass and its application to 2,3-butanediol production. Bioresour Technol. 2016;205:90-6. doi:10.1016/j.biortech.2016.01.028.

7. Pepe O, Ventorino V, Cavella S, Fagnano M, Brugno R. Prebiotic content of bread prepared with flour from immature wheat grain and selected dextran-producing lactic acid bacteria. Appl Environ Microbiol. 2013;79:3779-85. doi:10.1128/AEM.00502-13. 
8. Lee SY. Bacterial polyhydroxyalkanoates. Biotechnol Bioeng. 1996;49:114. doi:10.1002/(SICI)1097-0290(19960105)49:1<1:AID-BIT1>3.0.CO;2-P.

9. Steinbüchel A, Füchtenbusch B. Bacterial and other biological systems for polyester production. Trends Biotechnol. 1998;16:419-27. doi:10.1016/S0167-7799(98)01194-9.

10. Cavalheiro JMBT, De Almeida MCMD, Grandfils C, Da Fonseca MMR. Poly(3-hydroxybutyrate) production by Cupriavidus necator using waste glycerol. Process Biochem. 2009;44:509-15. doi:10.1016/j. procbio.2009.01.008.

11. Salehizadeh H, Van Loosdrecht MCM. Production of polyhydroxyalkanoates by mixed culture: recent trends and biotechnological importance. Biotechnol Adv. 2004;22:261-79. doi:10.1016/j. biotechadv.2003.09.003.

12. Ahn WS, Park SJ, Lee SY. Production of poly(3-hydroxybutyrate) from whey by cell recycle fed-batch culture of recombinant Escherichia coli. Biotechnol Lett. 2001;23:235-40. doi:10.1023/A:1005633418161.

13. Castilho LR, Mitchell DA, Freire DMG. Production of polyhydroxyalkanoates (PHAs) from waste materials and by-products by submerged and solid-state fermentation. Bioresour Technol. 2009;100:5996-6009. doi:10.1016/j.biortech.2009.03.088

14. Panico A, d'Antonio G, Esposito G, Frunzo L, lodice P, Pirozzi F. The effect of substrate-bulk interaction on hydrolysis modeling in anaerobic digestion process. Sustainability. 2014;6:8348-63. doi:10.3390/ su6128348.

15. Sans C, Mata-Alvarez J, Cecchi F, Pavan P, Bassetti A. Volatile fatty acids production by mesophilic fermentation of mechanically-sorted urban organic wastes in a plug-flow reactor. Bioresour Technol. 1995;51:89-96. doi:10.1016/0960-8524(95)95866-Z.

16. Chynoweth DP, Owens JM, Legrand R. Renewable methane from anaerobic digestion of biomass. Renew Energy. 2001;22:1-8. doi:10.1016/ S0960-1481(00)00019-7.

17. Patel SKS, Singh M, Kalia VC. Hydrogen and polyhydroxybutyrate producing abilities of Bacillus spp. from glucose in two stage system. Indian J Microbiol. 2011;51:418-23. doi:10.1007/s12088-011-0236-9.

18. Carvalho Morais C. Production of bacterial biopolymers from industrial fat-containing wastes. 2013. https://run.unl.pt/bitstream/10362/10922/1/Morais_2013.pdf. Accessed Sept 2013.

19. Koutinas AA, Xu Y, Wan R, Webb C. Polyhydroxybutyrate production from a novel feedstock derived from a wheat-based biorefinery. Enzyme Microb Technol. 2007;40:1035-44. doi:10.1016/j. enzmictec.2006.08.002.

20. Xu Y, Wanga RH, Koutinas AA, Webba C. Microbial biodegradable plastic production from a wheat-based biorefining strategy. Process Biochem. 2010:45:153-63. doi:10.1016/j.procbio.2009.09.001.

21. Haas R, Jin B, Zepf FT. Production of poly(3-hydroxybutyrate) from waste potato starch. Biosci Biotechnol Biochem. 2008;72:253-6. doi:10.1271/ bbb.70503.

22. Yu J, Stahl H. Microbial utilization and biopolyester synthesis of bagasse hydrolysates. Bioresour Technol. 2008;99:8042-8. doi:10.1016/j. biortech.2008.03.071.

23. Fukui T, Doi Y. Efficient production of polyhydroxyalkanoates from plant oils by Alcaligenes eutrophus and its recombinant strain. Appl Microbiol Biotechnol. 1998:49:333-6. doi:10.1007/s002530051178.

24. Kahar P, Tsuge T, Taguchi K, Doi Y. High yield production of polyhydroxyalkanoates from soybean oil by Ralstonia eutropha and its recombinant strain. Polym Degrad Stabil. 2004;83:79-86. doi:10.1016/ S0141-3910(03)00227-1.

25. Füchtenbusch B, Wullbrandt D, Steinbüchel A. Production of polyhydroxyalkanoic acids by Ralstonia eutropha and Pseudomonas oleovorans from an oil remaining from biotechnological rhamnose production. Appl Microbiol Biotechnol. 2000;53:167-72. doi:10.1007/s002530050004.

26. Yu J. Production of PHA from starchy wastewater via organic acids. J Biotechnol. 2001;86:105-12. doi:10.1016/S0168-1656(00)00405-3.

27. Wang J, Yu H. Biosynthesis of polyhydroxybutyrate (PHB) and extracellular polymeric substances (EPS) by Ralstonia eutropha ATCC 17699 in batch cultures. Appl Microbiol Biotechnol. 2007;75:871-8. doi:10.1007/ s00253-007-0870-7.

28. Jiang Y, Song X, Gong L, Li P, Dai C, Shao W. High poly $(\beta$ hydroxybutyrate) production by Pseudomonas fluorescens A2a5 from inexpensive substrates. Enzyme Microb Technol. 2007;42:167-72. doi:10.1016/j.enzmictec.2007.09.003.
29. Koller M, Bona R, Chiellini E, Fernandes EG, Horvat P, Kutschera C, Braunegg G. Polyhydroxyalkanoate production from whey by Pseudomonas hydrogenovora. Bioresour Technol. 2008;99:4854-63.

30. Cromwick AM, Foglia T, Lenz RW. The microbial production of poly(hydroxyalkanoates) from tallow. Appl Microbiol Biotechnol. 1996:46:464-9. doi:10.1007/s002530050845.

31. Hori K, Marsudi S, Unno H. Simultaneous production of polyhydroxyalkanoates and rhamnolipids by Pseudomonas aeruginosa. Biotechnol Bioeng. 2002:78:699-707. doi:10.1002/bit.10248.

32. Guo W, Song C, Kong M, Geng W, Wang Y, Wang S. Simultaneous production and characterization of medium-chain-length polyhydroxyalkanoates and alginate oligosaccharides by Pseudomonas mendocina NK-01. Appl Microbiol Biotechnol. 2011;92:791-801. doi:10.1007/ 500253-011-3333-0.

33. Page WJ, Manchak J, Rudy B. Formation of poly(hydroxybutyrate-cohydroxyvalerate) by Azotobacter vinelandii UWD. Appl Environ Microbiol. 1992;58:2866-73.

34. Chou K, Ryu HV, Park C, Goodrich P. Poly(hydroxybutyrate-co-hydroxyvalerate) from swine waste liquor by Azotobacter vinelandii UWD. Biotechnol Lett. 1997:19:7-10. doi:10.1023/A:1018342332141.

35. Kim BS. Production of poly-3-hydroxybutyrate from inexpensive substrates. Enzyme Microb Technol. 2000:27:772-7. doi:10.1016/ S0141-0229(00)00299-4.

36. Quagliano JC, Miyazaki SS. Biosynthesis of poly-beta-hydroxybutyrate and exopolysaccharides on Azotobacter chroococcum strain 6B utilizing simple and complex carbon sources. Appl Biochem Biotechnol. 1999:82:199-208 doi:10.1385/ABAB:82:3:199

37. Pal S, Manna A, Paul AK. Production of poly( $\beta$-hydroxybutyric acid) and exopolysaccharide by Azotobacter beijerinckii WDN-01. World J Microbiol Biotechnol. 1999;15:11-6.

38. Halami PM. Production of polyhydroxyalkanoate from starch by the native isolate Bacillus cereus CFR06. World J Microbiol Biotechnol. 2008:24:805-12. doi:10.1007/s11274-007-9543-z.

39. Yilmaz M, Beyatli Y. Poly-b-hydroxybutyrate (PHB) production by a Bacillus cereus M5 strain in sugarbeet molasses. Zuckerindustrie. 2005;130:109-12.

40. Law KH, Chenga YC, Leungb YC, Lob WH, Chuac H, Yua HF. Construction of recombinant Bacillus subtilis strains for polyhydroxyalkanoates synthesis. Biochem Eng J. 2003;16:203-8. doi:10.1016/ S1369-703X(03)00039-1.

41. Liu F, Li W, Ridgway D, Gu T. Production of poly- $\beta$-hydroxybutyrate on molasses by recombinant Escherichia coli. Biotechnol Lett. 1998;20:3458. doi:10.1023/A:1005367011378.

42. Lee SY, Middelberg APJ, Lee YK. Poly(3-hydroxybutyrate) production from whey using recombinant Escherichia coli. Biotechnol Lett. 1997;19:1033-5. doi:10.1023/A:1018411820580.

43. Nikel PI, de Almeida A, Melillo EC, Galvagno MA, Pettinari MJ. New recombinant Escherichia coli strain tailored for the production of poly(3-hydroxybutyrate) from agroindustrial by-products. Appl Environ Microbiol. 2006;72:3949-54.

44. Park SJ, Park JP, Lee SY. Production of poly(3-hydroxybutyrate) from whey by fed-batch culture of recombinant Escherichia coli in a pilot-scale fermenter. Biotechnol Lett. 2002;24:185-9. doi:10.102 3/A:1014196906095.

45. Nonato R, Mantelatto P, Rossell C. Integrated production of biodegradable plastic, sugar and ethanol. Appl Microbiol Biotechnol. 2001;57:1-5. doi:10.1007/s002530100732.

46. Silva LF, Taciro MK, Ramos MEM, Carter JM, Pradella JGC, Gomez JGC. Poly-3-hydroxybutyrate (P3HB) production by bacteria from xylose, glucose and sugarcane bagasse hydrolysate. J Ind Microbiol Biotechnol. 2004:31:245-54. doi:10.1007/s10295-004-0136-7.

47. Reddy CSK, Ghai R, Kalia VC. Polyhydroxyalkanoates: an overview. Bioresour Technol. 2003;87:137-46. doi:10.1016/ S0960-8524(02)00212-2.

48. Suriyamongkol P, Weselake R, Narine S, Moloney M, Shah S. Biotechnological approaches for the production of polyhydroxyalkanoates in microorganisms and plants-a review. Biotechnol Adv. 2007;25:148-75. doi:10.1016/j.biotechadv.2006.11.007.

49. Anderson AJ, Dawes EA. Occurrence, metabolism, metabolic role, and industrial uses of bacterial polyhydroxyalkanoates. Microbiol Rev. 1990;54:450-72. 
50. Taidi B, Anderson JA, Dawes EA, Byrom D. Effect of carbon source and concentration on the molecular mass of poly(3-hydroxybutyrate) produced by Methylobacterium extorquens and Alcaligenes eutrophus. Appl Microbiol Biotechnol. 1994;40:786-90. doi:10.1007/BF00173975.

51. Jendrossek D, Knoke I, Habibian RB, Steinbüchel A, Schlegel HG. Degradation of poly(3-hydroxybutyrate), PHB, by bacteria and purification of a novel PHB depolymerase from Comamonas sp. J Polym Environ. 1993;1:53-63. doi:10.1007/BF01457653.

52. Delafield FP, Doudoroff M, Palleroni NJ, Lusty CJ, Contopoulos R. Decomposition of poly- $\beta$-hydroxybutyrate by Pseudomonas. J Bacteriol. 1965:90:1455-66.

53. Tanio T, Fukui T, Shirakura Y, Saito T, Tomita K, Kaiho T, Masamune S. An extracellular poly(3-hydroxybutyrate) depolymerase from Alcaligenes faecalis. Eur J Biochem. 1982;124:71-7. doi:10.1111/j.1432-1033.1982. tb05907.x.

54. Mergaert J, Anderson C, Wouters A, Swings J. Microbial degradation of poly(3-hydroxybutyrate) and poly(3-hydroxybutyrate-co3-hydroxyvalerate) in compost. J Polym Environ. 1994;1994(2):177-83. doi:10.1007/BF02067443.

55. Mukai K, Yamada K, Doi Y. Efficient hydrolysis of polyhydroxyalkanoates by Pseudomonas stutzeri YM1414 isolated from lake water. Polym Degrad Stab. 1994:43:319-27. doi:10.1016/0141-3910(94)90002-7.

56. Patel M, Bastioli C, Marini L, Würdinger E. Life-cycle assessment of bio-based polymers and natural fiber composites. Biopolymers. 2003;10:409-52. doi:10.1002/3527600035.bpola014.

57. Akiyama M, Tsuge T, Doi Y. Environmental life cycle comparison of polyhydroxyalkanoates produced from renewable carbon resources by bacterial fermentation. Polym Degrad Stab. 2003;80:183-94. doi:10.1016/ S0141-3910(02)00400-7

58. Harding KG, Dennis JS, Von Blottnitz H, Harrison STL. Environmental analysis of plastic production processes: comparing petroleum-based polypropylene and polyethylene with biologically-based poly- $\beta$ hydroxybutyric acid using life cycle analysis. J Biotechnol. 2007;130:5766. doi:10.1016/j.jbiotec.2007.02.012.

59. Pietrini M, Roes L, Patel MK, Chiellini E. Comparative life cycle studies on poly(3-hydroxybutyrate)-based composites as potential replacement for conventional petrochemical plastics. Biomacromol. 2007;8:2210-8. doi:10.1021/bm0700892.

60. Atlić A, Koller M, Scherzer D, Kutschera C, Grillo-Fernandes E, Horvat P, Chiellini E, Braunegg G. Continuous production of poly([R]-3-hydroxybutyrate) by Cupriavidus necator in a multistage bioreactor cascade. Appl Microbiol Biotechnol. 2011;91:295-304. doi:10.1007/ s00253-011-3260-0.

61. Gholami A, Mohkam M, Rasoul-Amini S, Ghasemi Y. Industrial production of polyhydroxyalkanoates by bacteria: opportunities and challenges. Minerva Biotechnol. 2016;28:59-74.

62. Chanprateep S. Current trends in biodegradable polyhydroxyalkanoates. J Biosci Bioeng. 2010;874(110):621-32. doi:10.1016/j. jbiosc.2010.07.014.

63. Valentino F, Morgan-Sagastume F, Campanari S, Villano M, Werker A, Majone M. Carbon recovery from wastewater through bioconversion into biodegradable polymers. N Biotechnol. 2017;37:9-23. doi:10.1016/j. nbt.2016.05.007.

64. DeMarco S. Advances in polyhydroxyalkanoate production in bacteria for biodegradable plastics. Basic Biotechnol eJ. 2005;1:1-4.

65. Tian PY, Shang L, Ren H, Mi Y, Fan DD, Jiang M. Biosynthesis of polyhydroxyalkanoates: current research and development. Afr J Biotechnol. 2009:8:709-14. doi:10.5897/AJB.

66. Tsuge T. Metabolic improvements and use of inexpensive carbon sources in microbial production of polyhydroxyalkanoates. J Biosci Bioeng. 2002;94:579-84. doi:10.1016/S1389-1723(02)80198-0.

67. Füchtenbusch B, Steinbüchel A. Biosynthesis of polyhydroxyalkanoates from low-rank coal liquefaction products by Pseudomonas oleovorans and Rhodococcus ruber. Appl Microbiol Biotechnol. 1999;52:91-5. doi:10.1007/s002530051492.

68. Vandamme P, Coenye T. Taxonomy of the genus Cupriavidus: a tale of lost and found. Int J Syst Evol Microbiol. 2004;54:2285-9. doi:10.1099/ ijs.0.63247-0.

69. Lee SY. Poly(3-hydroxybutyrate) production from xylose by recombinant Escherichia coli. Bioprocess Eng. 1998;18:397-9. doi:10.1007/ s004490050462
70. Kalia VC, Raizada N, Sonakya V. Bioplastics. J Sci Ind Res. 2000;59:433-45.

71. Poomipuk N, Reungsang A, Plangklang P. Poly- $\beta$-hydroxyalkanoates production from cassava starch hydrolysate by Cupriavidus sp. KKU38. Int J Biol Macromol. 2014;65:51-64. doi:10.1016/j.ijbiomac.2014.01.002.

72. Bhatia SK, Shim YH, Jeon JM, Brigham CJ, Kim YH, Kim HJ, Lee YK. Starch based polyhydroxybutyrate production in engineered Escherichia coli. Bioprocess Biosyst Eng. 2015;38:1479-84.

73. Kulpreecha S, Boonruangthavorn A, Meksiriporn B, Thongchul N. Inexpensive fed-batch cultivation for high poly(3-hydroxybutyrate) production by a new isolate of Bacillus megaterium. J Biosci Bioeng. 2009;107:240-5. doi:10.1016/j.jbiosc.2008.10.006.

74. Di Pasqua R, Ventorino V, Aliberti A, Robertiello A, Faraco V, Viscardi S, Pepe O. Influence of different lignocellulose sources on endo-1, 4- $\beta$-glucanase gene expression and enzymatic activity of Bacillus amyloliquefaciens B31C. BioResources. 2014;9:1303-10. doi:10.15376/ biores.9.1.1303-1310.

75. Ventorino V, Parillo R, Testa A, Viscardi S, Espresso F, Pepe O. Chestnut green waste composting for sustainable forest management: microbiota dynamics and impact on plant disease control. J Environ Manag. 2016;166:168-77. doi:10.1016/j.jenvman.2015.10.018.

76. Ventorino V, Aliberti A, Faraco V, Robertiello A, Giacobbe S, Ercolini $D$, et al. Exploring the microbiota dynamics related to vegetable biomasses degradation and study of lignocellulose-degrading bacteria for industrial biotechnological application. Sci Rep. 2015;5:8161. doi:10.1038/srep08161.

77. Ventorino V, Ionata E, Birolo L, Montella S, Marcolongo L, de Chiaro A, Espresso F, Faraco V, Pepe O. Lignocellulose-adapted endo-cellulase producing Streptomyces strains for bioconversion of cellulose-based materials. Front Microbiol. 2016;7:2061. doi:10.3389/fmicb.2016.02061.

78. Kumar S, Abe H. Practical guide to microbial polyhydroxyalkanoates. 1st ed. Shawbury: iSmithers - A Smithers Group Company; 2010.

79. Saratale GD, Oh MK. Characterization of poly-3-hydroxybutyrate (PHB) produced from Ralstonia eutropha using an alkali-pretreated biomass feedstock. Int J Biol Macromol. 2015;80:627-35. doi:10.1016/j. ijbiomac.2015.07.034.

80. Tomizawa S, Chuah JA, Matsumoto K, Doi Y, Numata K. Understanding the limitations in the biosynthesis of polyhydroxyalkanoate (PHA) from lignin derivatives. ACS Sustain Chem Eng. 2014;2:1106-13. doi:10.1021/ sc500066f.

81. Zhong J, Stevens DK, Hansen CL. Optimization of anaerobic hydrogen and methane production from dairy processing waste using a two-stage digestion in induced bed reactors (IBR). Int J Hydrog Energy. 2015;40:5470-15476. doi:10.1016/j.ijhydene.2015.09.085.

82. Gomez JGC, Méndez BS, Nikel PI, Pettinari MJ, Prieto MA, Silva LF. Making green polymers even greener: towards sustainable production of polyhydroxyalkanoates from agroindustrial by-products. Adv Appl Biotechnol. 2012;2:42-62. doi:10.5772/31847.

83. Pries A, Steinbüchel A, Schlegel HG. Lactose-and galactose-utilizing strains of poly(hydroxyalkanoic acid)-accumulating Alcaligenes eutrophus and Pseudomonas saccharophila obtained by recombinant DNA technology. Appl Microbiol Biotechnol. 1990;33:410-7. doi:10.1007/ BF00176656.

84. Ganzeveld KJ, Van Hagen A, Van Agteren MH, de Koning W, Schoot Uiterkamp AJM. Upgrading of organic waste: production of the copolymer poly-3-hydroxybutyrate-co-valerate by Ralstonia eutropha with organic waste as sole carbon source. J Clean Prod. 1999;7:413-9. doi:10.1016/S0959-6526(99)00159-6.

85. Du G, Chen LXL, Yu J. High-efficiency production of bioplastics from biodegradable organic solids. J Polym Environ. 2004;12:89-94. doi:10.1023/B:JOOE.0000010054.58019.21.

86. Kumar SR, Mudliar SN, Reddy KMK, Chakrabarti T. Production of biodegradable plastics from activated sludge generated from a food processing industrial wastewater treatment plant. Bioresour Technol. 2004;95:327-30. doi:10.1016/j.biortech.2004.02.019.

87. Khardenavis AA, Kumar MS, Mudliar SN, Chakrabarti T. Biotechnological conversion of agro-industrial wastewaters into biodegradable plastic, poly $\beta$-hydroxybutyrate. Bioresour Technol. 2007;98:3579-84. doi:10.1016/j.biortech.2006.11.024.

88. Cameotra SS, Makkar RS. Synthesis of biosurfactants in extreme conditions. Appl Microbiol Biotechnol. 1998;50:520-9. doi:10.1007/ s002530051329. 
89. Ding Z, Bourven I, Guibaud G, van Hullebusch ED, Panico A, Pirozzi F, Esposito G. Role of extracellular polymeric substances (EPS) production in bioaggregation: application to wastewater treatment. App Microbiol Biotechnol. 2015;99:9883-905. doi:10.1007/s00253-015-6964-8.

90. Palomba S, Cavella S, Torrieri E, Piccolo A, Mazzei P, Blaiotta G, Ventorino $\checkmark$, Pepe O. Polyphasic screening, homopolysaccharide composition, and viscoelastic behavior of wheat sourdough from a Leuconostoc lactis and Lactobacillus curvatus exopolysaccharide-producing starter culture. Appl Environ Microbiol. 2012;78:2-12. doi:10.1128/AEM.07302-11.

91. Torrieri E, Pepe O, Ventorino V, Masi P, Cavella S. Effect of sourdough at different concentrations on quality and shelf life of bread. LWT Food Sci Technol. 2014;56:508-16. doi:10.1016/j.lwt.2013.12.005.

92. Liang TW, Wu CC, Cheng WT, Chen YC, Wang CL, Wang IL, Wang SL. Exopolysaccharides and antimicrobial biosurfactants produced by Paenibacillus macerans TKU029. Appl Biochem Biotechnol. 2014;172:93350. doi:10.1007/s12010-013-0568-5.

93. Lin SC. Biosurfactants: recent advances. J Chem Tech Biotechnol. 1996:66:109-20. doi:10.1002/ (SICI) 1097-4660(199606)66:2<109:AID-JCTB477>3.0.CO;2-2.

94. Desai DJ, Banat IM. Microbial production of surfactants and their commercial potential. Microbiol Mol Biol Rev. 1997;61:47-64.

95. Appels L, Baeyens J, Degrève J, Dewil R. Principles and potential of the anaerobic digestion of waste-activated sludge. Prog Energy Combust Sci. 2008;34:755-81. doi:10.1016/j.pecs.2008.06.002.

96. Lema JM, Omil F. Anaerobic treatment: a key technology for a sustainable management of wastes in Europe. Water Sci Technol. 2001:44:33-140.

97. Lettinga G. Digestion and degradation, air for life. Water Sci Technol. 2001:44:57-176.

98. Dung TNB, Sen B, Chen CC, Kumar G, Lin CY. Food waste to bioenergy via anaerobic processes. Energy Procedia. 2014;61:307-12. doi:10.1016/j. egypro.2014.11.1113.

99. Mancuso G, Langone M, Andreottola G. A swirling jet-induced cavitation to increase activated sludge solubilisation and aerobic sludge biodegradability. Ultrason Sonochem. 2017;35:489-501. doi:10.1016/j. ultsonch.2016.11.006.

100. Barton JR, Issaias I, Stentiford El. Carbon-making the right choice for waste management in developing countries. Waste Manag. 2008;28:69-76. doi:10.1016/j.wasman.2007.09.033.

101. Abbasi T, Tauseef SM, Abbasi SA. Anaerobic digestion for global warming control and energy generation -an overview. Renew Sustain Energy Rev. 2012;16:3228-42. doi:10.1016/j.rser.2012.02.046.

102. Bekkering J, Broekhuis AA, Van Gemert WJT. Optimisation of a green supply chain—a review. Bioresour Technol. 2010;101:450-6. doi:10.1016/j.biortech.2009.08.106.

103. Tambone F, Genevini P, D'Imporzano G, Adani F. Assessing amendment properties of digestate by studying the organic matter composition and the degree of biological stability during the anaerobic digestion of the organic fraction of MSW. Bioresour Technol. 2009;100:3140-2. doi:10.1016/j.biortech.2009.02.012.

104. Rehl T, Müller J. Life cycle assessment of biogas digestate processing technologies. Resour Conserv Recycl. 2011;56:92-104. doi:10.1016/j. resconrec.2011.08.007.

105. Mata-Alvarez J, Mace S, Llabres P. Anaerobic digestion of organic solid wastes. An overview of research achievements and perspectives. Bioresour Technol. 2000;74:3-16.

106. Kerroum D, Mossaab BL, Hassen MA. Production of bio-energy from organic waste: effect of temperature and substrate composition. Int J Energy Res. 2014;38:270-6. doi:10.1002/er.3044.

107. Ariunbaatar J, Di Perta ES, Panico A, Frunzo L, Esposito G, Lens PN, Pirozzi F. Effect of ammoniacal nitrogen on one-stage and two-stage anaerobic digestion of food waste. Waste Manag. 2015;38:388-98. doi:10.1016/j.wasman.2014.12.001.

108. Kim M, Ahn YH, Speece RE. Comparative process stability and efficiency of anaerobic digestion; mesophilic vs. thermophilic. Water Res. 2002:36:4369-85. doi:10.1016/S0043-1354(02)00147-1.

109. Kundu K, Sharma S, Sreekrishnan TR. Influence of process parameters on anaerobic digestion microbiome in bioenergy production: towards an improved understanding. BioEnergy Res. 2017;10:288-303. doi:10.1007/s12155-016-9789-0.
110. Novaes RFV. Microbiology of anaerobic digestion. Water Sci Technol. 1986;18:1-14

111. Gonzalez-Martinez A, Garcia-Ruiz MJ, Rodriguez-Sanchez A, Osorio F, Gonzalez-Lopez J. Archaeal and bacterial community dynamics and bioprocess performance of a bench-scale two-stage anaerobic digester. Appl Microbiol Biotechnol. 2016;100:6013-33. doi:10.1007/ s00253-016-7393-z.

112. Raposo F, De la Rubia MA, Fernández-Cegrí V, Borja R. Anaerobic digestion of solid organic substrates in batch mode: an overview relating to methane yields and experimental procedures. Renew Sustain Energy Rev. 2012:16:861-77. doi:10.1016/j.rser.2011.09.008.

113. Cirne DG, Paloumet X, Björnsson L, Alves MM, Mattiasson B. Anaerobic digestion of lipid-rich waste-effects of lipid concentration. Renew Energy. 2007;32:965-75. doi:10.1016/j.renene.2006.04.003.

114. Li C, Fang HHP. Fermentative hydrogen production from wastewater and solid wastes by mixed cultures. Crit Rev Environ Sci Technol. 2007:37:1-39. doi:10.1080/10643380600729071.

115. Neves L, Ribeiro R, Oliveira R, Alves MM. Enhancement of methane production from barley waste. Biomass Bioenergy. 2006;30:599-603. doi:10.1016/j.biombioe.2005.12.003.

116. Siegert I, Banks C. The effect of volatile fatty acid additions on the anaerobic digestion of cellulose and glucose in batch reactors. Process Biochem. 2005;40:3412-8. doi:10.1016/j.procbio.2005.01.025.

117. Callaghan FJ, Wase DAJ, Thayanity K, Forster CF. Continuous Codigestion of cattle slurry with fruit and vegetable wastes and chicken manure. Biomass Bioenergy. 2002;22:71-7. doi:10.1016/ S0961-9534(01)00057-5.

118. Cuetos MJ, Gómez X, Otero M, Morán A. Anaerobic digestion and co-digestion of slaughterhouse waste (SHW): influence of heat and pressure pre-treatment in biogas yield. Waste Manag. 2010;30:1780-9. doi:10.1016/j.wasman.2010.01.034

119. Edström M, Nordberg A, Thyselius L. Anaerobic treatment of animal byproducts from slaughterhouses at laboratory and pilot scale. Appl Biochem Biotechnol. 2003;109:127-38. doi:10.1385/ABAB:109:1-3:127.

120. Chen Y, Cheng JJ, Creamer KS. Inhibition of anaerobic digestion process: a review. Bioresour Technol. 2008;99:4044-64. doi:10.1016/j. biortech.2007.01.057.

121. Nielsen HB, Angelidaki I. Strategies for optimizing recovery of the biogas process following ammonia inhibition. Bioresour Technol. 2008:99:7995-8001. doi:10.1016/j.biortech.2008.03.049.

122. Limoli A, Langone M, Andreottola G. Ammonia removal from raw manure digestate by means of a turbulent mixing stripping process. J Environ Manag. 2016;176:1-10. doi:10.1016/j.jenvman.2016.03.007.

123. Zhang P, Zeng G, Zhang G, Li Y, Zhang B, Fan M. Anaerobic co-digestion of biosolids and organic fraction of municipal solid waste by sequencing batch process. Fuel Process Technol. 2008;89:485-9. doi:10.1016/j. fuproc.2007.11.013.

124. Hawkes DL. Factors affecting net energy production from mesophilic anaerobic digestion. In: Stafford DA, Wheatley BI, Hughes DE, editors. Anaerobic digestion. 1980. http://agris.fao.org/agris-search/search.do?r ecordID=US201301314196

125. Astals S, Musenze RS, Bai X, Tannock S, Tait S, Pratt S, Jensen PD. Anaerobic co-digestion of pig manure and algae: impact of intracellular algal products recovery on co-digestion performance. Bioresour Technol. 2015:181:97-104. doi:10.1016/j.biortech.2015.01.039.

126. Park S, Li YB. Evaluation of methane production and macronutrient degradation in the anaerobic co-digestion of algae biomass residue and lipid waste. Bioresour Technol. 2012;111:42-8. doi:10.1016/j. biortech.2012.01.160

127. Wang M, Park C. Investigation of anaerobic digestion of Chlorella sp. and Micractinium sp. grown in high-nitrogen wastewater and their codigestio with waste activated sludge. Biomass Bioenergy. 2015:80:30-7. doi:10.1016/j.biombioe.2015.04.028.

128. Zhong W, Chi L, Luo Y, Zhang Z, Zhang Z, Wu WM. Enhanced methane production from Taihu Lake blue algae by anaerobic co-digestion with corn straw in continuous feed digesters. Bioresour Technol. 2013;134:264-70. doi:10.1016/j.biortech.2013.02.060.

129. Zhen G, Lu X, Kobayashi T, Kumar G, Xu K. Anaerobic co-digestion on improving methane production from mixed microalgae (Scenedesmus sp., Chlorella sp.) and food waste: kinetic modeling and synergistic 
impact evaluation. Chem Eng J. 2016;299:332-41. doi:10.1016/j. cej.2016.04.118.

130. Angelidaki I, Sanders W. Assessment of the anaerobic biodegradability of macropollutants. Rev Environ Sci Biotechnol. 2004;3:117-29. doi:10.1007/s11157-004-2502-3.

131. Browne J, Nizami AS, Thamsiriroj T, Murphy JD. Assessing the cost of biofuel production with increasing penetration of the transport fuel market: a case study of gaseous biomethane in Ireland. Renew Sustain Energy Rev. 2011;15:4537-47. doi:10.1016/j.rser.2011.07.098.

132. Owens JM, Chynoweth DP. Biochemical methane potential of municipal solid waste (MSW) components. Water Sci Technol. 1993;27:1-14.

133. Hansen TL, Schmidt JE, Angelidaki I, Marca E, Jansen JLC, Mosbæk H. Method for determination of methane potentials of solid organic waste. Waste Manag. 2004;24:393-400. doi:10.1016/j.wasman.2003.09.009.

134. Xie S, Lawlor PG, Frost JP, Hud Z, Zhan X. Effect of pig manure to grass silage ratio on methane production in batch anaerobic co-digestion of concentrated pig manure and grass silage. Bioresour Technol. 2011;102:5728-33. doi:10.1016/j.biortech.2011.03.009.

135. Angelidaki I, Alves M, Bolzonella D, Borzacconi L, Campos JL, Guwy AJ, Kalyuzhnyi S, Jenicek P, van Lier JB. Defining the biomethane potentia (BMP) of solid organic wastes and energy crops: a proposed protocol for batch assays. Water Sci Technol. 2009:59:927-34. doi:10.2166/ wst.2009.040.

136. Esposito G, Frunzo L, Liotta F, Panico A, Pirozzi F. Bio-methane potential tests to measure the biogas production from the digestion and codigestion of complex organic substrates. Open Environ Eng J. 2012;5:1-8.

137. Yokoi H, Maki R, Hirose J, Hayashi S. Microbial production of hydrogen from starch-manufacturing wastes. Biomass Bioenergy. 2002;22:389-95. doi:10.1016/S0961-9534(02)00014-4.

138. Angenent LT, Khursheed K, Al-dahhan M, Wrenn BA, DominguezEspinoza R. Production of bioenergy and biochemicals from industrial and agricultural wastewater. Trends Biotechnol. 2004;22:477-85. doi:10.1016/j.tibtech.2004.07.001.

139. Shin HS, Youn JH, Kim HS. Hydrogen production from food waste in anaerobic mesophilic and thermophilic acidogenesis. Int J Hydrog Energy. 2004;29:1355-63. doi:10.1016/j.jijydene.2003.09.011.

140. O-Thong S, Prasertsan P, Birkeland NK. Evaluation of methods for preparing thermophilic hydrogen producing seeds from anaerobic digested sludge with microbial communities aspects. Bioresour Technol. 2009;100:909-18.

141. Nitipan S, Mamimin C, Intrasungkha N, Birkeland NK, Sompong O. Microbial community analysis of thermophilic mixed culture sludge for biohydrogen production from palm oil mill effluent. Int J Hydrog Energy. 2014;39:19285-93. doi:10.1016/j.ijhydene.2014.05.139.

142. Lin CY, Lay CH. Carbon/nitrogen-ratio effect on fermentative hydrogen production by mixed microflora. Int J Hydrog Energy. 2004;29:41-5. doi:10.1016/50360-3199(03)00083-1.

143. Prasertsan P, O-Thong S, Birkeland NK. Optimization and microbial community analysis for production of biohydrogen from palm oil mill effluent by thermophilic fermentative process. Int J Hydrog Energy. 2009;34:7448-59. doi:10.1016/j.jijhydene.2009.04.075.

144. Ghimire A, Frunzo L, Pirozzi F, Trably E, Escudie R, Lens PNL, Esposito G. A review on dark fermentative biohydrogen production from organic biomass: process parameters and use of by-products. Appl Energy. 2015;144:73-95. doi:10.1016/j.apenergy.2015.01.045.

145. Levin DB, Pitt L, Love M. Biohydrogen production: prospect sand limitations to practical application. Int J Hydrog Energy. 2004;29:173-85. doi:10.1016/50360-3199(03)00094-6.

146. Das D, Veziroglu TN. Hydrogen production by biological processes: a survey of literature. Int J Hydrog Energy. 2001;26:13-28. doi:10.1016/ S0360-3199(00)00058-6.

147. Miyake J, Miyake M, Asada Y. Biotechnological hydrogen production: research for efficient light energy conversion. J Biotechnol. 1999;70:89101. doi:10.1016/S0168-1656(99)00063-2.

148. Lo YC, Chen SD, Chen CY, Huang TI, Lin CY, Chang JS. Combining enzymatic hydrolysis and dark-photofermentation processes for hydrogen production from starch feedstock: a feasibility study. Int J Hydrog Energy. 2008;33:5224-33. doi:10.1016/j.jjhydene.2008.05.014.

149. Chen CY, Yang MH, Yeh KL, Liu CH, Chang JS. Biohydrogen production using sequential dark and photo fermentation processes. Int $\mathrm{J}$ Hydrog Energy. 2008;33:4755-62. doi:10.1016/j.jijhydene.2008.06.055.
150. Tao Y, Chen Y, Wu Y, He Y, Zhou Z. High hydrogen yield from a two-step process of dark- and photo-fermentation of sucrose. Int J Hydrog Energy. 2006;32:200-6. doi:10.1016/j.ijhydene.2006.06.034.

151. Pradhan N, Dipasquale L, d'Ippolito G, Panico A, Lens PN, Esposito G, Fontana A. Hydrogen production by the thermophilic bacterium Thermotoga neapolitana. Int J Mol Sci. 2015;16:12578-600. doi:10.1016/j. ijhydene.2016.01.107.

152. Hawkes FR, Hussy I, Kyazze G, Dinsdale R, Hawkes DL. Continuous dark fermentative hydrogen production by mesophilic microflora: principles and progress. Int J Hydrog Energy. 2007;32:172-84. doi:10.1016/j. ijhydene.2006.08.014.

153. Eroglu E, Melis A. Photobiological hydrogen production: recent advances and state of the art. Bioresour Technol. 2011;102:8403-13. doi:10.1016/j.biortech.2011.03.026.

154. Luongo V, Ghimire A, Frunzo L, Fabbricino M, D'Antonio G, Pirozzi F, Esposito G. Photofermentative production of hydrogen and poly- $\beta$ hydroxybutyrate from dark fermentation products. Bioresour Technol. 2016;228:171-5. doi:10.1016/j.biortech.2016.12.079.

155. Cappelletti M, Bucchi G, Mendes JD, Alberini A, Fedi S, Bertin L, Frascari D. Biohydrogen production from glucose, molasses and cheese whey by suspended and attached cells of four hyperthermophilic Thermotoga strains. J Chem Technol Biotechnol. 2012:87:1291-307. doi:10.1002/jctb.3782.

156. Nguyen TAD, Han SJ, Kim JP, Kim MS, Sim SJ. Thermophilic hydrogen fermentation from Korean rice straw by Thermotoga neapolitana. Int J Hydrog Energy. 2010;35:13392-8. doi:10.1016/j.ijhydene.2009.11.112.

157. Yu X, Drapcho CM. Hydrogen production by the hyperthermophilic bacterium Thermotoga neapolitana using agricultural-based carbon and nitrogen sources. Biol Eng Trans. 2011;4:101-11.

158. Davila-Vazquez G, Arriaga S, Alatriste-Mondrago F, De Leon-Rodrıguez A, Rosales-Colunga LM, Razo Flores E. Fermentative biohydrogen production: trends and perspectives. Environ Sci Biotechnol. 2008;7:27-45. doi:10.1007/s11157-007-9122.

159. Chen WM, Tseng ZJ, Lee KS, Chang JS. Fermentative hydrogen production with Clostridium butyricum CGS5 isolated from anaerobic sewage sludge. Int J Hydrog Energy. 2005;30:1063-70. doi:10.1016/j. ijhydene.2004.09.008.

160. Lo YC, Chen SD, Chen CY, Huang TI, Lin CY, Chang JS. Combining enzymatic hydrolysis and dark-photo fermentation processes for hydrogen production from starch feedstock: a feasibility study. Int J Hydrog Energy. 2008;33(5224):5233. doi:10.1016/j.jijydene.2008.05.014.

161. Ferchichi M, Crabbe E, Gil GHW, Almadidy A. Influence of initial pH on hydrogen production from cheese whey. J Biotechnol. 2005;120:402-9. doi:10.1016/j.jbiotec.2005.05.017.

162. Bisaillon A, Turcot J, Hallenbeck PC. The effect of nutrient limitation on hydrogen production by batch cultures of Escherichia coli. Int J Hydrog Energy. 2006;31:1504-8. doi:10.1016/j.ijhydene.2006.06.016.

163. Yasuda K, Tanisho S. Fermentative hydrogen production from artificial food wastes. In: Proceedings of the 16th world hydrogen energy conference. Lyon, France; 2006. p. 210.

164. Liu $H_{\text {, }}$ Zhang $\mathrm{T}$, Fang HHP. Thermophilic $\mathrm{H}_{2}$ production from a cellulosecontaining wastewater. Biotechnol Lett. 2003;25:365-9. doi:10.102 3/A:1022341113774.

165. Kumar G, Bakonyi P, Periyasamy S, Kim SH, Nemestóthy N, BélafiBakó K. Lignocellulose biohydrogen: practical challenges and recent progress. Renew Sustain Energy Rev. 2015;44:728-37. doi:10.1016/j. rser.2015.01.042.

166. Khanal SK, Chen WH, Li L, Sung SW. Biological hydrogen production: effects of $\mathrm{pH}$ and intermediate products. Int J Hydrog Energy. 2004;29:1123-31. doi:10.1016/j.ijhydene.2003.11.002.

167. Fang HHP, Liu H, Zhang T. Phototrophic hydrogen production from acetate and butyrate in wastewater. Int J Hydrog Energy. 2005;30:78593. doi:10.1016/j.ijhydene.2004.12.010.

168. Valdez-Vazquez I, Ríos-Leal E, Esparza-García F, Cecchi F, Poggi-Varaldo HM. Semi-continuous solid substrate anaerobic reactors for $\mathrm{H}_{2}$ production from organic waste: mesophilic versus thermophilic regime. Int J Hydrog Energy. 2005;30:13-4. doi:10.1016/j.jijhydene.2004.09.016.

169. Kumar G, Bakonyi P, Kobayashi T, Xu KQ, Sivagurunathan P, Kim SH, Bélafi-Bakó K. Enhancement of biofuel production via microbial augmentation: the case of dark fermentative hydrogen. Renew Sustain Energy Rev. 2016;57:879-91. doi:10.1016/j.rser.2015.12.107. 
170. Albuquerquea MGE, Martino V, Pollet E, Avérous L, Reis MAM. Mixed culture polyhydroxyalkanoate (PHA) production from volatile fatty acid (VFA)-rich streams: effect of substrate composition and feeding regime on PHA productivity, composition and properties. J Biotechnol. 2011;151:66-76. doi:10.1016/j.jbiotec.2010.10.070.

171. Morgan-Sagastume F, Karlsson A, Johansson P, Pratt S, Boon N, Lant P, Werker A. Production of polyhydroxyalkanoates in open, mixed cultures from a waste sludge stream containing high levels of soluble organics, nitrogen and phosphorus. Water Res. 2010;44:5196-211. doi:10.1016/j. watres.2010.06.043.

172. Chen GQ. A microbial polyhydroxyalkanoates (PHA) based bio-and materials industry. Chem Soc Rev. 2009;38:2434-46. doi:10.1039/ B812677C.

173. Serafim LS, Lemos PC, Albuquerque MG, Reis MA. Strategies for PHA production by mixed cultures and renewable waste materials. Appl Microbiol Biotechnol. 2008;81:615-28. doi:10.1007/s00253-008-1757-y.

174. Lee WS, Chua ASM, Yeoh HK, Ngoh GC. A review of the production and applications of waste-derived volatile fatty acids. Chem Eng J. 2014;235:83-99. doi:10.1016/j.cej.201309.002.

175. Saharan BS, Grewal A, Kumar P. Biotechnological production of polyhydroxyalkanoates: a review on trends and latest developments. Chin J Biol. 2014;80:29-84. doi:10.1155/2014/802984.

176. Wu SC, Liou SZ, Lee CM. Correlation between bio-hydrogen production and polyhydroxybutyrate (PHB) synthesis by Rhodopseudomonas palustris WP3-5. Bioresour Technol. 2012;113:44-50. doi:10.1016/j. biortech.2012.01.090.

177. Vincenzini M, Marchini A, Ena A, De Philippis R. $H_{2}$ and poly- $\beta$ hydroxybutyrate, two alternative chemicals from purple non sulfur bacteria. Biotechnol Lett. 1997;19:759-62. doi:10.1023/A:1018336209252.

178. Albuquerque MGE, Concas S, Bengtsson S, Reis MAM. Mixed culture polyhydroxyalkanoates production from sugar molasses: the use of a 2-stage CSTR system for culture selection. Bioresour Technol. 2010;101:7112-22. doi:10.1016/j.biortech.2010.04.019.

179. Buffière P, Loisel D, Bernet N, Delgenes JP. Towards new indicators for the prediction of solid waste anaerobic digestion properties. Water Sci Technol. 2006;53:233-41. doi:10.2166/wst.2006.254

180. Gunaseelan VN. Biochemical methane potential of fruits and vegetable solid waste feedstocks. Biomass Bioenergy. 2004;26:389-99. doi:10.1016/j.biombioe.2003.08.00.

181. Zubr J. Methanogenic fermentation of fresh and ensiled plant materials. Biomass. 1986;11:159-71. doi:10.1016/0144-4565(86)90064-8.

182. Mähnert $P$, Heiermann $M$, Linke B. Batch- and semi-continuous biogas production from different grass species. Agric Eng. 2005;7:1-11.

183. Liu G, Zhang R, El-Mashad HM, Dong R. Effect of feed to inoculum ratios on biogas yields of food and green wastes. BioResources. 2009;100:5103-8. doi:10.1016/j.biortech.2009.03.08.

184. Scaglione D, Caffaz S, Ficara E, Malpei F, Lubello C. A simple method to evaluate the short-term biogas yield in anaerobic codigestion of was and organic wastes. Water Sci Technol. 2008;58:1615-22. doi:10.2166/ wst.2008.502.

185. Tong X, Smith LH, McCarty PL. Methane fermentation of selected lignocellulosic materials. Biomass. 1990;21:239-55. doi:10.1016/0144-4565(90)90075-U.

186. Shanmugam P, Horan NJ. Simple and rapid methods to evaluate methane potential and biomass yield for a range of mixed solid wastes. Bioresour Technol. 2009;100:471-4. doi:10.1016/j.biortech.2008.06.027.

187. Dinuccio E, Balsari P, Gioelli F, Menardo S. Evaluation of the biogas productivity potential of some Italian agro-industrial biomasses. Bioresour Technol. 2010;101:3780-3. doi:10.1016/j.biortech.2009.12.113.

188. El-Mashad HM, Zhang R. Biogas production from co-digestion of dairy manure and food waste. Bioresour Technol. 2010;101:4021-8. doi:10.1016/j.biortech.2010.01.027.

189. Pommier S, Llamas AM, Lefebvre X. Analysis of the outcome of shredding pretreatment on the anaerobic biodegradability of paper and cardboard materials. Bioresour Technol. 2010;101:463-8. doi:10.1016/j. biortech.2009.07.034.

190. Paepatung N, Nopharatana A, Songkasiri W. Bio-methane potential of biological solid materials and agricultural wastes. Asian J Energy Environ. 2009;10:19-27.

191. Parawira W, Murto M, Zvauya R, Mattiasson B. Anaerobic batch digestion of solid potato waste alone and in combination with sugar beet leaves. Renew Energy. 2004;29:1811-23. doi:10.1016/j. renene.2004.02.005

192. Sharma SK, Mishra IM, Sharma MP, Saini JS. Effect of particle size on biogas generation from biomass residues. Biomass. 1988;17:251-63. doi:10.1016/0144-4565(88)90107-2.

193. Lehtomäki A, Viinikainen TA, Rintala JA. Screening boreal energy crops and crop residues for methane biofuel production. Biomass Bioenergy. 2008;32:541-50. doi:10.1016/j.biombioe.2007.11.013.

194. Amon T, Amon B, Kryvoruchko V, Machmüller A, Hopfner-Sixt K, Bodiroza $V$. Methane production through anaerobic digestion of various energy crops grown in sustainable crop rotations. Bioresour Technol. 2007;98:3204-12. doi:10.1016/j.biortech.2006.07.007.

195. Jokela JPY, Vavilin VA, Rintala JA. Hydrolysis rates, methane production and nitrogen solubilisation of grey waste components during anaerobic degradation. Bioresour Technol. 2005;96:501-8. doi:10.1016/j. biortech.2004.03.009.

196. Bauer A, Leonhartsberger C, Bösch P, Amon B, Friedl A, Amon T. Analysis of methane yields from energy crops and agricultural by-products and estimation of energy potential from sustainable crop rotation systems in EU-27. Clean Technol Environ Policy. 2010;12:153-61. doi:10.1007/ s10098-009-0236-1.

197. Zhang P, Chen Y, Zhou Q. Waste activated sludge hydrolysis and shortchain fatty acids accumulation under mesophilic and thermophilic conditions: effect of pH. Water Res. 2009;43:3735-42. doi:10.1016/j. watres.2009.05.036

198. Jiang S, Chen Y, Zhou Q, Gu G. Biological short-chain fatty acids (SCFAs) production from waste-activated sludge affected by surfactant. Water Res. 2007:41:3112-20. doi:10.1016/j.watres.2007.03.039.

199. Ji Z, Chen G, Chen Y. Effects of waste activated sludge and surfactant addition on primary sludge hydrolysis and short-chain fatty acids accumulation. Bioresour Technol. 2010;101:3457. doi:10.1016/j. biortech.2009.12.117.

200. Wu H, Yang D, Zhou Q, Song Z. The effect of $\mathrm{pH}$ on anaerobic fermentation of primary sludge at room temperature. J Hazard Mater. 2009;172:196-201. doi:10.1016/j.jhazmat.2009.06.146.

201. Elbeshbishy E, Hafez H, Dhar BR, Nakhla G. Single and combined effect of various pretreatment methods for biohydrogen production from food waste. Int J Hydrog Energy. 2011;36:11379-87. doi:10.1016/j. ijhydene.2011.02.067.

202. Kim HJ, Kim SH, Choi YG, Kim GD, Chung TH. Effect of enzymatic pretreatment on acid fermentation of food waste. J Chem Technol Biotechnol. 2006;81:974-80. doi:10.1002/jctb.1484.

203. Zhang B, Zhang LL, Zhang SC, Shi HZ, Cai WM. The influence of $\mathrm{pH}$ on hydrolysis and acidogenesis of kitchen wastes in twophase anaerobic digestion. Environ Technol. 2005;26:329-40. doi:10.1080/09593332608618563.

204. Bolzonella D, Fatone F, Pavan P, Cecchi F. Anaerobic fermentation of organic municipal solid wastes for the production of soluble organic compounds. Ind Eng Chem Res. 2005;44:3412-8. doi:10.1021/ ie048937m.

205. Hong SK, Shirai Y, Nor Aini AR, Hassan MA. Semi-continuous and continuous anaerobic treatment of palm oil mill effluent for the production of organic acids and polyhydroxyalkanoates. J Environ Sci. 2009;3:552-9.

206. Beccari M, Bertin L, Dionisi D, Fava F, Lampis S, Majone M, Valentino F, Vallini G, Villano M. Exploiting olive oil mill effluents as a renewable resource for production of biodegradable polymers through a combined anaerobic-aerobic process. J Chem Technol Biotechnol. 2009;84:901-8. doi:10.1002/jctb.2173.

207. Bengtsson S, Hallquist J, Werker A, Welander T. Acidogenic fermentation of industrial wastewaters: effects of chemostat retention time and $\mathrm{pH}$ on volatile fatty acids production. Biochem Eng J. 2008;40:492-9. doi:10.1016/j.bej.2008.02.004. 